\title{
Nationalism and Islam in Cold War Turkey, 1944-69
}

\author{
ILKER AYTÜRK*
}

In the introduction to his popular study of the history of Turkish nationalism, Ilhan E. Darendelioğlu, a nationalist and anti-communist journalist, complained that for many years Turkish nationalism suffered from an unfair association with Kemalism. From its moment of birth, which antedated the republic, Turkish nationalism was imbued with the Islamic spirit, according to the author, but secularist militancy of the Kemalist ruling elite had spread the fundamentally wrong image that all nationalists lost touch with the religion of their people. 'This book ... will clearly prove', Darendelioglu wrote in the late 1960s, 'that, today, Turkish nationalism returned back to the Turkish-Islamic consciousness, which was its previous and real source; and the futility and fragility of an irreligious patriotism devoid of a sacred belief system has long been understood.' ${ }^{1}$ The belief that Turkish national identity cannot be disentangled from its Islamic context dominates the academic study of Turkish nationalism as well. Gökhan Çetinsaya, for example, claims that there was no essential 'contradiction' between religion (Islam) and nationalism in Turkish political thought ${ }^{2}$ and that those "who reject Islam as a crucial component of Turkish nationalism are exceptional, such as in Kemalist nationalism and Turanism'. 3

This view is problematic for a number of reasons. First of all, a theory which aims to explain the relationship between Turkish nationalism and Islam has scarcely any explanatory value if it writes off the two hugely influential, Kemalist and Turanist, varieties of nationalism as mere exceptions to the norm. Secondly, 'the harmony thesis' is not corroborated by facts. The typical Turkish nationalist of the period extending from 1908 to 1944, which witnessed the rise of 'the first generation' of Turkish nationalism, was not an Islamic-leaning conservative. On the contrary, with very few exceptions, he or she would generally espouse a progressive and revolutionary set of ideas for those years, which were meant to transcend the late Ottoman status quo. In vast numbers, Turkish nationalists supported the transformation from empire to a republic, carried out a series of westernizing reforms and did not object to the symbolic reforms of the early republic which aimed to make Turkey and the Turks look more western, and championed full legal and political equality for women and their integration into public life. Most importantly, the first generation of Turkish

*Department of Political Science and Public Administration, Bilkent University, 06800 Bilkent, Ankara, Turkey. E-mail: ayturk@bilkent.edu.tr 
nationalists were, again with few exceptions, a secular and secularizing elite. The best example of the attitude of this generation toward religion can be found in none other than Ziya Gökalp (1876-1924), arguably the most important ideologue of Turkish nationalism in the twentieth century. Basically, Gökalp regarded the Islamic civilization as a spent force and did not expect it to resume its long-gone glory in the modern world; that is why he recommended that the Turks switch to the western, European world of nations. The role he reserved for Islam in the construction of Turkish national identity, on the other hand, is manifestly subordinate when compared with the role played by ethnic culture. ${ }^{4}$ His programme for the Turkification of Islam, which included translation of the Arabic call to prayer (ezan) and the Koran into Turkish by the government and the employment of this official translation in Muslim prayers, was going to become a major source of embarrassment for future generations of Turkish nationalists. ${ }^{5}$ In other words, Turkish nationalism was born at the turn of the century as a secular, positivist and revolutionary ideology and the hegemony of Islam over Turkish culture and society was undoubtedly part of what nationalists revolted against. It is no wonder pan-Islamists and pan-Turkists regarded each other as ideological adversaries in the 1910s and were locked in a battle of ideas that was fought in the late Ottoman press to the bitter end.

Whether or not there is a contradiction between nationalism and Islam has basically been a theological question which has occupied and divided Turkish Islamists for more than a century now. Turkish nationalists, on the other hand, walked a much more pragmatic and non-doctrinaire path. Knowing too well that they were operating in a predominantly Muslim environment, nationalists of all stripes either embraced Islam or were prepared to include it as a building block of Turkish national identity to varying degrees. In that sense, one could easily make the case that Kemalists and Turanists did not constitute exceptions either, because they, too, spared room for their sanitized version of Islam in the making of Turkishness. Therefore, while all important ideologues of Turkish nationalism in the twentieth century agreed with the 'harmony thesis' in principle, this does not change the fact that the precise role of Islam in the construction of Turkish national identity was and continues to be the inevitable and most hotly debated topic of their books, journals, pamphlets, speeches and private conversations. Arguably, there was no other dispute that pitted factions of nationalists against each other with the same level of intensity and rancour. ${ }^{6}$

This article maintains that the 'harmony thesis' obscures a rich history of nationalist reflections on Islam. It aims to transcend the discourse of harmony by shifting the focus to those reflections and debates. Indeed Turkish nationalists did not see a contradiction between nationalism and Islam. But of tension there was plenty. Amusingly, the situation resembled Christological debates on the exact nature of Jesus in early Christianity. Was Jesus human, or divine, or both? And if both, how did those two combine in his person? The Nicene Creed was the response to those questions and it settled the problem - at least for mainstream Christians - by declaring that Jesus was both fully human and fully divine, and those two natures co-existed in his person in a Hypostatic Union, which we mortals could hardly fathom. Unfortunately for Turkish nationalists, they could not formulate a Nicene Creed of their own. Their failure to reconcile authoritatively the Islamic and ethnic components of Turkish identity proved to be the Achilles' heel of the movement and it has, up to this day, 
exposed them in the most compromising way to their bitterest rivals in the Turkish right, the political Islamists.

The time span to be covered in this article overlaps with the onset and deepening of the Cold War, the point of departure being the Racism-Turanism trials of 1944. From the late nineteenth century to 1944, Turkish nationalists preserved a façade of unity, while disputes over doctrine or daily politics were systematically swept under the carpet. The year 1944, however, witnessed a break in the ranks, as Kemalists took legal action against Racist-Turanists and purged them from positions of influence. The impact of the trials on Turkish public opinion and intelligentsia was profound: Kemalists finally dissociated themselves from ethnic nationalism in discourse, if not always in practice; and radical nationalist individuals, who had so far been tolerated or even welcomed within the ruling Kemalist bloc, suddenly found themselves personae non gratae. The fact that some nationalists had now become opponents of the Turkish regime was a first in republican history. In this sense, 1944 should be considered a turning point in the history of Turkish nationalism. The end date, on the other hand, is 1969, when the Nationalist Action Party, was born as the political arm of the nationalist movement at the Adana Congress of 1969, an event that also confirmed and consolidated the Islamic turn in Turkish nationalism.

The history of Turkish nationalist thought in the aftermath of the Second World War is a much-neglected field. This undeserved neglect is the outcome of two biases that we encounter in the academic studies on Turkish nationalism. The first bias is the widespread conviction that Turkish nationalism, just like other nationalisms for that matter, is mere rhetoric and thus not worthy of scholarly attention. Bringing to mind Benedict Anderson's famous indictment that 'unlike other isms, nationalism has never produced its own grand thinkers: no Hobbeses, Tocquevilles, Marxes or Webers', 7 the few specialists in the field of Turkish nationalism generally focused on the history of nationalist institutions only, ignoring immense ideological transformations which took place within Turkish nationalist thought after $1944 .^{8}$

The second bias, on the other hand, is temporal: whereas the history of Turkish nationalism before 1944 and after 1980 has received some academic attention, it is not an exaggeration to call the period between those years the movement's terra incognita. Even those scholars who studied the history of nationalist thought in Turkey tended to concentrate on such topics as the genesis of Turkish nationalism at the end of the nineteenth century, ${ }^{9}$ the impact of Ziya Gökalp, ethnic and cultural nationalism in the early republican era, ${ }^{10}$ and, finally, the emergence of a racist movement in the early 1940s. ${ }^{11}$ Post-1980 developments have also received some attention. ${ }^{12}$ The second bias in the field, in other words, is the assumption that all developments of ideological significance in the history of nationalist ideas had already taken place before $1944,{ }^{13}$ and that after this date nationalist thought atrophied and, instead of shaping nationalist politics and activism on the streets, it trailed behind them.

Obviously, Turkish nationalism did not produce another Ziya Gökalp between 1944 and 1980, or since. However, this article takes issue with the dominant tendency in the literature, which considers this period barren and uninteresting from the vantage point of the history of ideas. On the contrary, as this article aims to show, Cold War years were rife with ideological tension between various nationalist factions 
such as the Racist-Turanists, ${ }^{14}$ the Anatolianists (Anadolucular), ${ }^{15}$ the Intellectuals' Hearth Movement (Aydinlar Ocağ $)^{16}$ as well as the National-Strugglists (Milli Mücadeleciler), ${ }^{17}$ to name just the most prominent groups. The debate on the relationship between national identity and Islam was going to be the most important fault line dividing them.

Kemalist attitudes toward Islam ranged from patronizing reformism to outright hostility. This is a particularly well-studied aspect of the Kemalist Revolution. ${ }^{18}$ As expected, Kemalism - to the extent that we could talk about it as a monolithic ideology - aimed to cast a national identity for the Turkish-speaking Muslim population of the republic and to base this identity on the secular pillars of ethnic language and history/memory. ${ }^{19}$ However, another attribute, Islam, was either ignored or, when that was not possible, it was incorporated as an instrument of control whose archaic mould, it was hoped, could temporarily contain social unrest, that is until this function too became superfluous as a result of Kemalist modernization. In the eyes of Kemalists, Islam was an integral part - if not the main cause - of an unfortunate package of poverty, backwardness and political impotence. This Kemalist view of Islam was not going to change until the coup d'etat of 1980, when the generals, makers of the Kemalist ideology and its guardians, finally decided to allow a greater role for Islam in order to combat the rising tide of socialism in Turkey. Be that as it may, Kemalist attitudes toward Islam remained more or less stagnant from 1923 to 1980 and the historian of this period is unlikely to chance upon a hidden surprise.

Therefore, the main protagonists of this article are the non-Kemalist nationalists, who fell out with the Turkish government in 1944. This group, too, was far from being monolithic and lacked a common roadmap for political action. Nominally, they were all nationalists, but they disagreed profoundly over what that meant exactly. What really united them more than anything else was their opposition to communism, on the one hand, and the single-party regime of the Republican People's Party (RPP), on the other. Even there, one could detect different shades of opposition. While some distinguished between the two early republican presidents, Kemal Atatürk and İsmet İnönü - usually blaming everything on the latter - others thought both equally dreadful. Another disagreement centred on the legacy of the Kemalist Revolution. On the one hand, there were extremists who regarded the Kemalist reforms as a malignant growth in the otherwise robust frame of the TurkishMuslim body politic and prescribed a root and branch extirpation, a Kemalectomy that would bring this sacrilegious episode to an end once and for all. Others, however, raised objections either on pragmatic grounds (Kemalists were still powerful; was it a good idea to declare total war on them?), or in principle (those Kemalist reforms which strengthened the nation-state could be retained, whereas the rest ought to be discarded). Furthermore, a significant generational gap separated secular nationalists such as Riza Nur $(1879-1942),{ }^{20}$ Nihal Atsız $(1905-75)^{21}$ and Nejdet Sançar (1910-75), ${ }^{22}$ who were born before 1923 and tended to be Racist-Turanists, from later generations of Islamic-leaning nationalists. This obvious diversity within the group defied attempts to find a proper name to describe and distinguish them from the official, Kemalist branch of Turkish nationalism. Various proposals to call them radical nationalists, ${ }^{23}$ hyper- or ultra-nationalists, ${ }^{24}$ right-wing nationalists ${ }^{25}$ and nationalist-conservatives or nationalist-sacredists ${ }^{26}$ are all problematic. The first 
three - the radical, the hyper and the ultra - reflect a normative, value-laden approach to the phenomenon of nationalism, whereas the last two are not comprehensive enough. Right-wing nationalism, on the other hand, sounds like a better term at first glance, but its applicability to an aggressively secular branch of nationalism, such as Racist-Turanism, is questionable. Therefore, despite its clumsiness, the term 'non-Kemalist nationalism' comes closest to capturing the essence of their common denominator.

Although the 1944 trials targeted the Racist-Turanists in particular, the crushing impact of official repression nearly eliminated all competing interpretations of Turkish national identity. By 1945 and 1946, when Turkey was undergoing another political revolution and becoming a multiparty democracy, the non-Kemalist nationalists in opposition were disconnected and powerless. Continued pressure at that point could have completely destroyed the last vestiges of their political influence, leaving the Kemalist variety as the hegemonic nationalist discourse. Indeed, if the RPP governments did not choose to silence them altogether, it was partly due to the recognition, on the part of the authorities, that these non-Kemalist nationalists, who were now considered beyond the pale of respectability, could still be useful against the leftists in the emerging Cold War environment. ${ }^{27}$

There is also reason to attribute the RPP's tolerance to necessities of daily politics. From its foundation in 1946 to the 14 May 1950 general elections, the Democratic Party (DP) emerged as the main rival to the ruling RPP. Founders of the DP were actually a splinter group from the RPP, who accused their former party of curtailing religious - that is, Islamic - freedom as well as ruining the Turkish economy by excessive central planning. The Democrats occupied the centre-right of the political spectrum and promised liberal economic reforms and a still secular but more respectful attitude toward Islam. As Turkey slowly evolved into a multiparty democracy, competition between the two parties was fierce. ${ }^{28}$ In all likelihood, the RPP leadership was more lenient on the radical right than expected simply because, in this way, they could divide the right into moderate and radical camps and break the monopoly of the Democrats on the right-wing vote.

If that was RPP's back-up plan, it did work for a couple of years. Kenan Öner, an Istanbul lawyer who made a name for himself by taking on the former Minister of Education Hasan Âli Yücel in a lengthy court battle, ${ }^{29}$ emerged as a leading spokesperson of right-wing interests in the second half of the 1940s and first joined the DP in 1946, becoming the chairman of the party branch in İstanbul. Öner's extremist views on Islam, the RPP and the Kemalist reforms, however, veered too far to the right for the DP mainstream's middle-of-the-road approach. Therefore, as early as 1947, articles calling for a 'nationalist' party started to appear in the journals of the radical right. In an interview he gave to Kizllelma, Nihal Atsiz, the intellectual leader of the non-Kemalist nationalists, described the Democrats as 'accomplices' in the then 25-year-long RPP authoritarianism and, while he said the Democrats could be preferred over the RPP, Atsiz still invited all the Turkists - a euphemism for RacistTuranists, the main non-Kemalist nationalist group at the time - to establish a party of their own. Atsiz believed a nationalist party could garner 25-30 per cent of the votes. ${ }^{30}$ Another author, who wrote under a nationalist alias, drew attention repeatedly - probably with an insider's knowledge of Öner's activities - to the need for a nationalist party and agreed with Atsiz that the Democrats were no different 
from the RPP when it came to diluting Turkish national identity by admitting Armenians, Greeks and Jews into Turkishness. ${ }^{31}$

This right-wing coalition finally established the Millet Partisi (Nation Party, NP) in July $1948 .^{32}$ The recently retired chief of the general staff of the early republic, Marshall Fevzi Çakmak, assumed honorary leadership of the party. Çakmak was widely recognized as one of the three founding giants of the republic, ${ }^{33}$ a natural successor to Atatürk in 1938, and the only other systemic actor that could rival and balance the leader of the RPP, President İsmet İnönü. Ironically, Çakmak's leadership was a greater threat to the DP than it was to the RPP, because had Öner and Cakmak been able to campaign more energetically, there is no doubt that the NP could have captured a big chunk of the DP votes. Both however were quite infirm and, conveniently for the DP, Öner died in 1949 and Çakmak in 1950, only one month before the general elections, a factor that explains the massive defection of the NP voters to the DP. All in all, the NP's initial success confirmed the existence of an alienated mass of radical right-wing voters, composed of the non-Kemalist nationalists and the Islamists, who were not satisfied with the DP's 'meek' opposition to the RPP. It also showed the viability of a party, based on that grassroots. From the late 1940s to the 1960s, this voter base and its political representatives were collectively known as the milliyetçi-mukaddesatçılar, a term that would roughly translate as nationalists who respect and uphold sacred Islamic values.

The most important characteristic of the milliyetçi-mukkadesatçı NP grassroots was that it represented an instinctive but uncomfortable blend of nationalism and Islam, which found its main outlet in opposing Kemalism and communism simultaneously. Modern techniques of measuring and analysing voting behaviour were unknown then, but public opinion surveys conducted in the 1960s may shed some light on earlier trends. ${ }^{34}$ Those studies indicate that republican-Kemalist values such as nationalism and secularism did not seep into the uneducated and largely illiterate rural periphery, which continued to take its inspiration from age-old local traditions and Islam. Therefore, the NP grassroots in the Turkish periphery inclined more towards an Islamic lifestyle and values than nationalism.

The situation was quite the reverse in the case of right-wing students at higher education institutions who were gradually rising to prominence: new, right-wing members of the Turkish intelligentsia such as Nurettin Topçu (1909-75), Osman Yüksel Serdengeçti (1917-83), İsmail Hakkı Yılanlığlu (1918-92), Hikmet Tanyu (1918-92), Bekir Berk (1926-93), Fethi Gemuhluoğlu (1922-77), Dündar Taşer (1925-72), Seyyid Ahmet Arvasi (1932-88), Nevzat Kösoğlu (b. 1940), Yücel Hacaloğlu (b. 1936), Erol Güngör (1938-83), Galip Erdem (1930-97), Ayvaz Gökdemir (1942-2008), Sadi Somuncuoğlu (b. 1940) and Taha Akyol (b. 1946) were put off by the excesses of the Turkish laïcité just like the conservative, Islamic periphery from which they almost invariably sprang. But, as much as they held Islam in the highest regard, they still considered nationalism the other most important value-system that shaped their worldviews, on a par with Islam. In that, one could discern a subtle, but by no means insignificant, gap that separated the right-wing intelligentsia from the milliyetçi-mukkadesatçı masses that they were going to lead.

These right-wing authors, poets, artists, journalists and bureaucrats had already become a fast-growing and very visible minority within the Turkish intelligentsia by 
the 1940s and their numbers and influence were going to increase in the 1950s, 1960s and 1970s. Most of them were born and raised in villages or small towns in the Turkish periphery and graduated from provincial high schools. During those formative early years, their political socialization took place in their patriarchal, conservative households or clandestine religious brotherhoods. Thus, when they first arrived in Istanbul or Ankara for university studies, the cultural shock was immense. The positivistic, rationalist, secular and often bohemian outlook that dominated the academic and the literary world as well as the art scene offended their sensibilities; gender equality and women's participation in public life hurt their sense of honour; overall, they tended to blame this 'urban decadence' on the RPP and the Kemalist super-westernization. ${ }^{35}$ Nevertheless, the non-Kemalist, anti-RPP, right-wing intelligentsia was staunchly nationalist too, partly as a result of the Kemalist education system and partly because, in contradistinction to Islam, nationalism offered a more legitimate and officially admissible grounds for opposition to the RPP in those years.

After the 14 May 1950 general elections, the former NP grassroots continued to exist as a discontented milliyetçi-mukaddesatçı voter group within the $\mathrm{DP}^{36}$ and they brought enormous pressure to bear on the right-wing intelligentsia to unite and either convince the DP leaders to adopt a more conservative, Islamist and ethnic nationalist stance, or to reorganize separately outside the political umbrella of the DP. The call for unity was very timely because, on the eve of the DP victory in 1950 and in its aftermath, the right-wing intelligentsia was tormented by internal rifts and ideological polarization. Brothers Nihal Atsiz and Nejdet Sançar, for example, who belonged to the earlier generation of secular nationalists, re-emerged as the most important spokesmen of non-Kemalist nationalism and their journal Orkun (1950-52) became the premier forum for criticizing the RPP legacy. Atsız and Sançar's racism was no longer as fashionable as it used to be in the early 1940s and their secular predisposition irritated many. However, Atsiz was still a hero in the eyes of all conservatives for being one of the courageous few who openly and loudly criticized Atatürk, Ínönü and the Kemalist Revolution during the single-party era. ${ }^{37}$ Having spent several years in prison and sacrificed his academic career for this cause, Atsiz now hoped to lead the Turkish nationalists as their ideological mentor. But that was an extremely unlikely scenario: the new, post-1944 recruits to the cause of Turkish nationalism, the so-called 'younger generation', did not necessarily share Atsiz's enthusiasm for pan-Turanianism; they were upset by Atsiz's secularist, unorthodox approach toward Islam; and, finally, they were reluctant to promote to a leadership position a man who was known for ruthlessly excluding anyone who disagreed with him.

Yet pressure from the grassroots was such that some attempts were made to bring all non-Kemalist nationalists - both secular and Islamist factions - together within a single organizational framework. In April 1950, representatives of several nationalist societies and organizations based in Ankara, İstanbul and other provincial towns met in İstanbul and established the Milliyetçiler Federasyonu (Federation of Nationalists) as the first step toward unification. Bekir Berk, a young Istanbul lawyer who was known as a radical, nationalist critic of Kemalism and the RPP, was elected the chairman of this representative body and his bimonthly journal Komünizme Karşı Mücadele became the organ of the Federation. ${ }^{38}$ Berk managed to host a diverse group of nationalist figures at their first major event on 14 December 1950, when 
right-wing celebrities including Minister of Education Tevfik Ileri, the famous nationalist poet Arif Nihat Asya, the emerging leader of the Anatolianism movement Nurettin Topçu, and Atsız's associate İsmet Tümtürk paraded before a large audience. ${ }^{39}$ After their first annual meeting on 1 April 1951, Berk announced in the name of the representatives of all constitutive societies and organizations that they agreed on the non-affiliated and above-parties status of the Federation - an important statement given the crushing victory of the DP the previous year - and that they were determined to protect the sacred values (mukaddesat) of the Muslim-Turkish youth. Berk also disclosed their decision to take one step further toward unification by abolishing all constitutive societies and organizations and redesigning the Federation as a society, which would then represent Turkish nationalists of all stripes. ${ }^{40}$ After a long discussion, the Federation of Nationalists was renamed the Turkish Nationalists Society (Türk Milliyetçiler Derne ği or TNS).

An eight-member committee prepared a draft statute and defined the aim of the TNS as 'bringing all nationalists together and advancing Turkish nationalism, based on the principles of God [Allah], homeland, history, language, tradition, art, family, morality, freedom and national sacred values [milli mukaddesat]. ${ }^{41}$ The fact that a reference to God was made in the statute and that God preceded all other so-called objective and subjective elements of national identity was a novelty in the history of Turkish nationalism, and did not fail to ignite opposition from the audience. One unnamed representative argued that the reference to God ought to be deleted, because God was intrinsically alluded to in the concept of 'national sacred values'. Another representative, Fethi Gemuhluoğlu, disagreed: nations could have different sets of 'sacred values', he said, and unlike in the case of Turkish nationalism, those did not necessarily include God. Even when they did, Gemuhluoglu claimed, the content is subject to change during times of 'mass neurosis' - an obvious allusion to the Kemalist Revolution. After the discussion, the statute was put to a vote and accepted by a great majority - without any changes. ${ }^{42}$

There were other signs of Islamization of the non-Kemalist nationalist movement, now represented by the TNS. Two Democrat members of parliament, Sait Bilgiç and Tahsin Tola, were emblematic of the trend of a new type of nationalist, who combined nationalism with a strong dose of Islam. Both were quite active in the TNS and Bilgiç was actually elected to preside over the annual meetings in 1951 and 1952. What made their role special was that both Bilgiç and Tola represented the province of Isparta, where the founder of the Nurculuk movement, Said Nursi, ${ }^{43}$ lived in exile from 1926 onward. The two had extensive contacts with the Kurdish cleric, who was at the time patiently building the most influential Islamic movement of twentiethcentury Turkey. Tola was particularly close to the Nurcu leader: he obtained the long-awaited permit to publish Said Nursi's works in the Roman alphabet and acted as the unofficial messenger between the movement and Prime Minister Adnan Menderes. $^{44}$

Another unmistakeable sign of Islamization was the elevation of Ayasofya into a symbol of Turkish nationalism. ${ }^{45}$ The Church of Hagia Sophia was consecrated in the sixth century AD as the seat of the Orthodox patriarch of Constantinople and remained so until the Ottoman conquest in 1453, after which it was converted into Muslim use and came to be known as the Ayasofya Mosque. In 1935, Atatürk reconverted the building into a museum, thereby stirring a controversy that goes on to this 
day. What remained until the 1950s as a quarrel strictly between the Kemalists and the conservative Islamists expanded after 1952 to include the non-Kemalist nationalists as well. As the 500th anniversary of the Ottoman conquest of İstanbul was approaching, the TNS took the opportunity to join the campaign to reverse the decision of 1935 and reopen Ayasofya as a mosque. ${ }^{46}$ The allure of appropriating Ayasofya as a symbol of Turkish nationalism was so captivating that even the otherwise secularist Atsiz could not resist the temptation and fantasized - in a characteristically quixotic fashion - about forming a band of lightly armed followers who would forcibly take over the building from guards and then perform the first Islamic prayers there in two decades. ${ }^{47}$

There were, however, limits to Atsiz's fantasies and also to the extent to which he could tolerate the increasingly religious overtones of the new discourse of nationalism. Altan Deliorman, who was then a young but very close associate of Atsiz, described the situation at the TNS as a 'coalition' between the disciples of Nurettin Topçu, Remzi Oğuz Arık ${ }^{48}$ and Atsız, a very broad spectrum that included the mukaddesatçılar, the Anatolianists and, finally, the Racist-Turanists. ${ }^{49}$ Although they tried hard to downplay ideological differences, this was clearly a marriage of convenience, consummated more by perceptions of common enemies than natural affinity. While Atsı's journal Orkun published numerous articles in support of the mukaddesatçlar, shielding them from accusations in the Kemalist press of being reactionaries (mürteciler) ${ }^{50}$ Atsiz himself did not hide his displeasure with the rising tide of religious fervour. ${ }^{51}$ Without outside intervention, tensions between the secular and the religious factions within the TNS would most probably have reached boiling point as early as the mid-1950s. A rupture, however, was not going to occur, or rather it was postponed until the 1960s, because an increasingly nervous DP government decided to intervene and terminate the activities of the TNS.

On the verge of being liquidated as a political movement in 1944, the non-Kemalist nationalists - both secular and religious - were given a second lease of life first by the RPP, and then by the Democrats to be employed as the proverbial firing squad, who could be (and were) extremely useful against the leftists and whose activities could easily be disowned by the government. Yet two things seem to have bothered the DP government in the early 1950s. First, these radical activists, who coalesced around the TNS, did not make do with attacking the left-wingers only, but actually often preferred to lash out against Atatürk, İnönü, the Kemalist reforms and especially the principle of laïcité. The Democrats were delighted if Inönü, the leader of the main opposition party, was their victim; however, the DP leadership, and particularly President Bayar, had no tolerance for angry outbursts against Atatürk, and when dozens of Atatürk statues were vandalized in 1950 and $1951,{ }^{52}$ the DP government responded with Law No.5816 Concerning Crimes against Atatürk, passed on 31 July 1951, making defamation of Atatürk a punishable crime. Moreover, the DP leadership was also alarmed by the growing number of TNS branches all over the country - more than 80 in 1953 - and probably wanted to prevent an impending schism. Thus, Prime Minister Menderes used the assassination attempt on the liberal journalist Ahmet Emin Yalman as a pretext to crack down on the radical right and in a speech on 17 January 1953 he gave the first signal of a wave of tough measures that brought to mind the stormy year $1944 .{ }^{53}$ On 22 January, an Ankara court ordered all TNS branches to cease their activities; on 31 January, the Isparta MPs 
Bilgiç and Tola were expelled from the DP; and, finally, on 4 April, the court closed down the three-year-old TNS. ${ }^{54}$

Coupled with the almost forcible government takeover of the Istanbul Fetih Cemiyeti (İstanbul Conquest Society) ${ }^{55}$ Atsız's appointment to an isolating position at the Süleymaniye Library of Manuscripts, Tevfik İleri's removal from the cabinet and the closure of the Nation Party in 1954 on charges of anti-secularism, these measures confirmed the crystallization of a state policy of marginalizing the political influence of radical right-wing nationalism. This, however, was not a purge and was never meant to be. The DP leadership did not intend to antagonize a large voter group, which they considered a natural component of their party base, all the more so when the 1954 general elections were approaching. Rather, the outcome of this intra-party crisis took the shape of a compromise: with the TNS gone, non-Kemalist nationalists were now expected to refrain from autonomous behaviour and to limit their activities strictly to the anti-communist front; in return, they would be allowed to remain in the governing right-wing DP bloc. This modus vivendi, which showed both the strengths and weaknesses of the non-Kemalist nationalists, was going to be sealed in 1954 with the readmission of Bilgiç and Tola into the DP group in the parliament.

Despite Atsı's objections, the non-Kemalist nationalists kept a low profile and respected the terms of this compromise for the rest of the 1950s. In the meanwhile, Islamization of the nationalist movement continued unabated. Three individuals contributed more than anyone else during the 1950s to the popularization of a new version of Turkish nationalism, which was now increasingly stripped from its association with secularism and westernization and, instead, was being reinvented as Muslim-Turkish nationalism. Two of those individuals, İsmail Hâmi Danişmend and Osman Zeki Yüksel (Serdengeçti) could hardly be called ideologues. They were not systematic thinkers and did not leave behind a distinct nationalist school of thought or a hard-core group of followers. Their great achievement, however, was to coin new discourses and slogans to disseminate nationalism among those segments of the Turkish society who had thus far been unreceptive to secular nationalist propaganda. In other words, the nationalist worldview, which could not penetrate the Turkish periphery in its Kemalist version, now started to make significant inroads in its newly fashioned Islamic guise.

While largely ignored in the literature, Danişmend's 1959 book, Türk Irkı Niçin Müslüman Olmuştur ${ }^{56}$ (Why Did the Turkish Race Convert to Islam?), contained nearly all of the most important themes of the Turkish-Islamic discourse for decades to come. Danişmend argued that Umayyad racism, which favoured Arabs, prevented conversion of Turks to Islam until the tenth and eleventh centuries, but otherwise Turks had a natural predisposition towards Islam. Their pre-Islamic religion centred on a single, omnipotent God in heaven; Turks believed in the eternity of the human soul and a second life after death in another world; and the ideal of jihad was a perfect match for their ambition to expand out of the Inner Asian steppe. ${ }^{57}$ Danişmend considered the Turkish path to Islam a 'magnificent exception' in that, of all the other Muslim peoples who converted after being conquered by the Arab armies in the early years of Islam, the Turkish conversion was not preceded by conquest. ${ }^{58}$ If anything, it was the Qarakhanid Turks who conquered the Muslim Samanids in 
Transoxiana and then embraced the new faith voluntarily, because Islam was only a more sophisticated form of their former religion. Danişmend's description of preIslamic Turks as "proto-Muslims, ${ }^{59}$ was destined to appear again and again in the Turkish nationalist literature as a justification for the Islamic turn. ${ }^{60}$ Furthermore, Danişmend maintained that Islam and Turkishness had become inseparable, not only because of natural affinity, but also for the reason that this was a mutually beneficial relationship: Turks saved Sunni Islam from its external - Byzantium and the Crusaders - and internal - Shiite Buyid and Fatimid dynasties - enemies; in return, Islam opened up the way before them to the West, provided Turkic dynasties from India to the Mediterranean with religious legitimacy, and helped preserve the Turkish ethnic identity. ${ }^{61}$

Compared to Danişmend, Serdengeçti was an incomparably more popular figure in the milliyetçi-mukaddesatçı circles due to his antinomian, one-man struggle against the Kemalist political and social order. ${ }^{62}$ He survived the 1944 trials, but was dismissed from Ankara University, after which he lost all faith in the system and started an Islamic-nationalist crusade against the RPP and the Kemalist establishment in his journal Serdengeçti (1947-62). ${ }^{63}$ It was in this journal that he invented the legendary slogan, which would be taken on by successive nationalist parties: Tanrı Dağl Kadar Türk, Hira Dă̆̆ Kadar Müslümanız (We are as Turkish as Mount Tengri and as Muslim as Mount Hira). Serdengeçti's use of two historically significant mountains as metaphors for emphasizing the inseparability of the Turkish and Islamic components of Turkish identity resonated among the milliyetçi-mukaddesatçı youth. Tengri or the Tian Shan Mountains in Central Asia are associated with the historic homeland of the ancient Turkic peoples, whereas Mount Hira was where Prophet Muhammad is believed to have received the first revelation from God.

Unlike the former two, Nurettin Topçu was a more sophisticated thinker and should be considered an ideologue rather than a popularizer. ${ }^{64}$ The first Turk ever to get a Sorbonne $\mathrm{PhD}$ in philosophy, Topçu began a lifelong teaching career in Turkish high schools in 1935. In Paris, Topçu was under the double influence of the religious-modernist French philosopher Maurice Blondel and the Anatolianist Remzi Oğuz Arık, who was a fellow Turkish graduate student at the Sorbonne. Back in Turkey, he attempted to produce a synthesis of Blondel and Arik with the help of new sources of inspiration. His father-in-law Hüseyin Avni Ulaş, a silenced opponent of Atatürk and İnönü, bequeathed to him an intense anti-Kemalism; Naqshbandi sheikh Abdülaziz Bekkine, on the other hand, introduced Topçu to sufism and taught him the availability of another path to Islam as 'lived experience', far removed from the Islam of the official ulema, whom Topçu greatly disliked. The contours of this synthesis began to appear in Topçu's famous journal Hareket published intermittently from 1939 until his death in 1975 - and in several powerful books. ${ }^{65}$ In those, he argued that the Sunni Islamic faith provided the necessary élan vital for the Seljuk and Ottoman Turkish expansion in the past and it would fulfil the same function again if modern-day Anatolian Sunni Muslims resolved the double binds of positivist Kemalism and formalist Islam of the ulema, both equally devoid of philosophical depth according to Topçu. The emphasis on Sunnism was impossible to overestimate. Topçu's vision of nationalism, for example, approached Turkish Alevis - approximately 20 per cent of the Turkish population - with great suspicion and nearly excluded them because of their former contacts with Shiite Safavid Iran. 
Nevertheless, Topçu's critique of contemporary Islam as an empty shell was already making things complicated for his milliyetçi-mukaddesatçı audience, who were interested in simple, jingoistic messages of unity in their fight against Kemalism and communism. When he started to make passing references to Islamic socialism in the 1960s, many of his followers deserted his cause, except for a devoted few, who continued to spread his message and contributed to a great revival of interest in Topçu after the 1980s.

During its golden age from 1908 to 1944, that is when it gradually became the dominant ideology of the late imperial and early republican intelligentsia, Turkish nationalism could be described as a positivist, westernizing and secular framework of thought. Following the break between the Kemalist and non-Kemalist nationalists in 1944, that outlook was going to change drastically. The schism of 1944 was essentially a result of disagreements between Kemalists and the Racist-Turanist Atsiz circle over questions of racism and homeland. ${ }^{66}$ However, in the aftermath of the 1944 trials the non-Kemalist nationalists branched off into several groups and while Atsiz and his followers were being increasingly marginalized, the Islamic and Anatoliacentred discourse challenged Atsiz's secular racism, which aimed to unite all Turks in the world. The shift in the discourse was exemplified by the huge popularity of Danişmend, Serdengeçti and Topçu as new, alternative leaders of opinion. The vast majority of young converts to various branches of non-Kemalist nationalism revered Atsiz as a giant of nationalist thought and as a model to be emulated, but they were not really interested in Atsiz's rebellion against Kemalism on racist and Turanist grounds. Those were his battles, not theirs. As a matter of fact, on Islam, that one issue which was so much dearer to them, Atsiz was dangerously close to the Kemalists.

Atsiz was also aware in the early 1950s that developments on his home turf threatened to cut the ground from under him. At that point, he could have responded by modifying his position slightly to make room for at least some Islamic content so that all non-Kemalist nationalists could close ranks around him. A move along those lines could have indeed transformed him into the undisputed leader of non-Kemalist nationalism and his movement into a formidable force in Turkish politics. Such was the divisive potential of the question of Islam, however, that the middle ground could not be found. On the contrary, his commitment to secular Turkish nationalism became even more entrenched and he began to see the Sunni Islamic influence, which went hand in hand with Anatolianism, as a great threat to the Turkish nation, comparable to the threat posed by communism. ${ }^{67}$ Atsiz was never going to attempt to repeat the right-wing coalition of the TNS experiment again and, what is more, whatever remained of that coalition after Atsız's attacks on Topçu and Danişmend in the latter half of the 1950s collapsed altogether when a group of young army officers toppled the DP government in 1960 and ushered in an entirely new era in Turkish politics.

The coup d'état of 1960 was a watershed event in the history of Turkish nationalism. The officers' committee, which took over the government, was not united by a common cause, ${ }^{68}$ and as a result in the first few months after the takeover power was concentrated in the hands of a faction called the Fourteen, led by Colonel Alparslan Türkeş. Türkeş was not a stranger to nationalist circles. ${ }^{69} \mathrm{He}$ had long-standing contacts with Atsız dating back to the 1930s and he was the only army officer charged 
with Racist-Turanism at the 1944 trials. He was exonerated in 1947, returned to the army, but continued to have a reputation for being a diehard nationalist. Therefore, his ascent to power kindled hopes that military rule would turn into a nationalist dictatorship. Those hopes were soon dashed, because other members of the officers' committee grew restive over Türkeş' increasing autonomy and, finally, eliminated the junta of the Fourteen by exiling them to Turkish embassies abroad. ${ }^{70}$

That was not the end of the story, however. During those few months that he wielded real power in Ankara, Türkeş convinced a core group of non-Kemalist nationalists - and possibly Atsiz - that he was the long-expected political leader of Turkish nationalism. Thus, his exile was seen as a temporary setback and even from New Delhi, where he was posted, Türkeş prepared the ground for his return. ${ }^{71}$ In other words, from 1960 onwards the decades-old dream of establishing a nationalist party and coming to power alone suddenly looked like a realistic goal. The stipulations of the 1961 Constitution, too, were going to fragment the Turkish political centre further and pave the way for new political parties on the left and the right. Under those circumstances, the question of party doctrine - and who would shape and articulate it - became an imminent concern. It is no coincidence that the on-going rift between the Atsiz circle and the Islamic-leaning Anatolianists burst into the open right at that juncture.

The opening salvo in this battle was a pamphlet, published by Atsiz in 1961, attacking Ali Fuad Başgil, an elderly professor of constitutional law who was known in the nationalist circles for his Anatolianist views. ${ }^{72}$ Then came Atsız's open intervention into the editorial policy of the nationalist, pro-Türkeş journal Milli Yol. The editor of the journal was Atsız's close associate İsmet Tümtürk, but their decades-old camaraderie did not help Tümtürk when he published a number of articles in the journal with the hope of endearing Türkeş to the more Islamic-leaning nationalists as well. One of those articles portrayed Türkeş as a 'pious colonel' (imanll albay), who neither smoked nor drank alcohol, and who lectured his five children on religion and morality after dinner. ${ }^{73}$ Worse, Tümtürk also tried to reach out to the beleaguered Nurcus - followers of Said Nursi - to win them over to the Türkeş camp. ${ }^{74}$ Atsız's response was swift: Millî Yol ceased publication immediately, and in the last issue of the journal Tümtürk attributed this decision to the 'disapproval of some well-known individuals in the nationalist front'. ${ }^{75}$ Not only did this episode display the power of Atsız in 1962, but it also showed the divisive potential of Islam among nationalists, so much so that it ruined Atsiz's relationship with Tümtürk.

Roughly around the same time, Atsız founded the Society of Turkists (Türkçüler Derne $\breve{g}$ i) as an exclusively Racist-Turanist forum, which he expected to keep under his thumb. ${ }^{76}$ Drawing a lesson from the TNS experience, Atsiz was now obsessively stringent about admitting new members and determined to keep nationalists with even the slightest Islamist inclination out of this organization. Already in 1963, however, Atsız was facing a rising tide of the milliyetçi-mukaddesatçıs, whose numbers grew by leaps and bounds compared to a handful of recruits he was able to make. To be able to establish full control over the branches of society, Atsiz sent his young disciple Altan Deliorman on a tour of Anatolian towns. Deliorman returned back with disheartening news and summarized his observations in a report: he only heard complaints from people he talked to, particularly about Atsiz's stance against the Nurcus 
and other Islamists; this was staining the movement's reputation and driving a wedge between nationalists and conservatives, Deliorman argued. Faced with this stark reality, Atsiz did not flinch. If those branches did not follow his instructions, he thought it would be better to close them down. Incidentally, he also began to suspect that Deliorman, too, had gone over to the Islamist side and the two rapidly parted ways after this incident. ${ }^{77}$

The slowly simmering conflict between the Atsiz circle and the Islamic-leaning nationalists also resulted in a public confrontation in the summer of 1963 during another study/inspection visit to Izmir by Atsız's brother Nejdet Sançar. There are no reliable records of what exactly happened, but Kemal Fedai Coşkuner recounted that a serious argument broke out at one of Sançar's talks between Sançar and those in the audience who found his views on Islam very offensive. ${ }^{78}$ Since Coşkuner himself was very critical of Atsiz at that point, it is possible that he embellished the story and inflated the proportions of the quarrel. Yet it is clear that a series of events in 1962 and 1963 convinced Atsız and Sançar that while secular nationalists were gradually being outnumbered and marginalized, nationalists who amalgamated their ethnic identity with Islam came to dominate the movement numerically. From that point on, Atsız, Sançar and other prominent members of their circle declared war on political Islamists, Anatolianists, Nurcus - that is, anyone who offered an alternative paradigm on the right which did not recognize the supremacy of racial-ethnic bonds over religion. ${ }^{79}$

Atsız and Sançar coined a new term for their opponents in this struggle, calling them 'political Islamists' (siyasî ümmetçiler), this being the first appearance of the term in Turkish political history. ${ }^{80}$ Sançar described the political Islamist as someone who believes that, (a) all Muslims constitute one single political entity and, hence, should be subject to an overarching Muslim state, (b) nationalism is un-Islamic because it divides the Muslim ummah and (c) Turkey as a nation-state and Turkishness as an identity are therefore irrelevant. ${ }^{81}$ Defined as such, Atsız, Sançar and their followers disagreed with political Islam profoundly on several grounds and attacked it fiercely.

To begin with, they regarded religion and nationalism as two essentially different and potentially competing ideologies for organizing human society. In Islam, they saw an antiquated social order, one that was not in harmony with the Zeitgeist and therefore slowly crumbling under the onslaught of modernity. The Islamic ulema, for instance, only reminded them of 'preachers of medieval dogma', 82 or 'pro-Arab and Arabic-loving bigots, whose days are over'. ${ }^{83}$ Nationalism, on the other hand, had become the organizing principle of modern international society since the end of the First World War and President Wilson's Fourteen Points. ${ }^{84}$ Under these new conditions, Islam, Atsiz claimed, might 'survive as long as it could keep up with life', and even then it should be separated from state affairs and be confined to the private sphere as a matter of individual conscience. ${ }^{85}$ Atsiz did not refrain from declaring nationalism superior to religion in terms of the chivalry and nobility of the idea, because:

[Nationalism] is a feeling of self-sacrifice. It is the idea of sacrificing oneself without expecting anything in return. In this regard, it is even superior to religion. The religious man sacrifices himself in order to obtain God's favour and entry 
into paradise in another world. This kind of sacrifice cannot be compared with the self-sacrifice of the nationalist, who hurls himself into the dark pit of oblivion without any personal gain. ${ }^{86}$

To compare religion with nationalism and find it wanting was a daring move for a right-wing leader in those days, but Atsiz had the nerve to put that it in writing.

Second, members of the Atsiz circle were also strongly opinionated about the role of Islam in the making of Turkish identity. Their writings are full of comparisons of race/ethnicity versus religion in the make-up of a modern Turk, and they unambiguously prioritized blood relationship and ethnic bonds over all other markers of national identity. Membership in a nation could not be a voluntary act according to this view; on the contrary, it is an unavoidable and unchangeable fact of nature, which overrides every other adopted and secondary feeling of belonging. Therefore, Islam, which requires a voluntary declaration of faith, cannot undo or significantly alter what members of a nation inherit genetically from their ancestors. It is no surprise that when Sançar defined the Turkish nation as 'a society, connected by bonds of race/ethnicity (soy), language, culture, common goals, homeland, history and religion', 87 he placed religion at the bottom of this carefully worded hierarchy of ingredients.

Demoting religion to a subordinate role showed how the Atsiz circle was categorically different from all milliyetçi-mukaddesatçı groups and especially from the Anatolianists. The latter had long been arguing that conversion to Islam was a defining moment not only in Turkish history, but also in the Turkish national character and transformed the erstwhile barbarian nomads into founders of 'the illustrious TurkishIslamic civilisation'. This strategy, which obviously aimed to disown the pre-Islamic and, in the case of the Anatolianists, the pre-Anatolian - portion of Turkish history, enraged the secular Racist-Turanists. The impact of Islam should not be exaggerated, wrote Sançar, because Turkish history is a seamless whole, rendered indivisible by the ethnic-racial Turkish character:

History is witness to the fact that the Turk's power to establish great states and to rule the course of history is in his nature as a gift from God.... Our nation does not owe this spiritual power to anything other than qualities inherent in its race. ... If an unmatched power, bestowed by God, did not exist in the Turkish race, that is, if the [Turks], too, were an ordinary society like other nations, would religion be enough to sustain military, social, humanistic accomplishments and those magnificent states continuously for centuries? ... If Islam [alone] had granted the opportunity and power to establish great states and to rule the course of history, should not we have expected other Muslim nations to become magnificent societies just like Turks? But what use is religion, if the nation does not have the right qualities? ${ }^{88}$

Likewise, they objected to the increasingly common use of terms such as the 'Muslim-Turkish nation' or 'Muslim-Turkish morality'. The Turks already have a name, blurted Hayrani Ilgar, a young disciple of Atsiz; they are simply called the Turkish nation. To add the adjective 'Muslim' was both wrong and of no use. ${ }^{89}$ It was patently wrong, because the emphasis on the Sunni Muslim identity threatened 
to divide the Turkish nation into secular and pious communities in addition to the concern that it discriminated against the sizeable community of non-Sunni, Alevi Turks and those others who did not profess any religion at all. ${ }^{90}$

Third, the Atsiz circle's opposition to political Islam brought to the fore a theoretically very interesting question: who is a right-winger in Turkey? Atsız and Sançar complained justifiably that there was great confusion in Turkish political thought regarding the terms 'left' and 'right'. Atsız, Sançar and their disciples were considered right-wingers on account of their nationalism and unbridled hatred for communism; but Atsiz also disclosed that their firm belief in the need for social justice made them appreciate leftist socio-economic policies. ${ }^{91}$ More importantly, they refused to be put in the same right-wing basket with their right-wing enemies. Anyone who is an enemy of communism was categorized as a right-winger, both Atsız and Sançar protested, which reduced the Turkish right into a disjointed, incoherent front, a hodgepodge of isolated groups and their opinion leaders who were not even on talking terms with one another. How could the Turkists of the Atsiz circle be ranked together with the 'bigoted political Islamists', who maintained that 'if you die for the nation [and not for the cause of Islam] you go to hell'? ${ }^{92}$ Political Islamists were fighting for the unification of all Muslims and therefore they were internationalists, opined Atsız; and, like all other 'internationalist cosmopolitans', they should rather be called leftists. 'We [alone] are the rightists: the Turkists', he proclaimed proudly. ${ }^{93}$

Finally, Atsız and Sançar denounced political Islam as the modern face of Arab imperialism, which had, for centuries, enslaved the hearts and minds of the Turkish people. Turks wasted their 'national energy' for the sake of religion and fought and killed one another in Sunni versus Shiite sectarian wars. They were wooed into believing that their language, Turkish, was worthless, that their ancestors were barbarian pagans, that it was a sin to give their children Turkish names, that they became civilized people only after the encounter with Islam. All this was nonsense according to Atsiz: Turks need not get involved in the row between Ali and Muawiyah; they should be mourning the death of Kür Şad and not the martyrdom of Husayn; they should be avenging the fall of Kazan and Crimea and not that of Muslim Spain. ${ }^{94}$ Atsiz did not fail to mention a widely held belief in Turkey that the Arabs stabbed the Ottoman Empire in the back during the First World War. ${ }^{95}$ Now the political Islamists were betraying the Turkish nation once again by denying its history and culture, and hence its very existence. In that sense, they were as dangerous as the communists.

Although Atsiz and his followers often targeted rival nationalist or Islamist opinion leaders such as Ali Fuat Başgil, Nurettin Topçu, Münevver Ayaşlı and Necip Fazil Kisakürek, ${ }^{96}$ it seems that they focused particularly on the Nurcus and the Nurculuk Movement after 1963. For Atsız, Nurcus were 'a foolish herd shepherded by an ignorant Kurd called Said-i Nursî', 'a bunch of losers, who get together to read the books Said-i Nursî wrote in his incomprehensible Kurdish-Turkish, as if they are studying atomic physics or a theorem by Einstein'. ${ }^{97}$ Said himself was regarded as a Kurdish nationalist and an enemy of the Turkish nation, a regrettable product of the short-sighted policies of the early republic, when the Turkish state did not fulfil its mission to educate a new generation of Turkish ulema. ${ }^{98}$ As a matter of fact, the debate on the Nurcus presented Atsız and Sançar with the perfect opportunity to clarify their views on Islam and to dispel widely circulating rumours that Atsiz 
and his circle converted to Shamanism, the pre-Islamic religion of the Turks. Atsiz, for example, repeatedly gave his blessing to the imam-hatip schools in the hope that enlightened religious scholars and prayer leaders could push back 'ignorant Kurds' such as Said Nursi. ${ }^{99}$ Sançar made an open declaration of his faith in Islam to be able to reassure those who were scared away from Racist-Turanism by the accusation of apostasy:

Here is the truth: I am one of the millions of Muslim Turks. But let me say this right away that if I were a shamanist, I would declare that, too, without hesitation. Because belief in one religion or another is a completely private matter and it is nobody's business. Yes, I am a Muslim Turk. But a Muslim Turk, who opposes bigotry and use of religion for political gain. ${ }^{100}$

Likewise, they continued to encourage conversion of the Ayasofya Museum into a mosque $^{101}$ and committed themselves publicly to the formula: "Turkishness and Islam are two holy, fundamental sources [of Turkish identity], which infused each other and combined inextricably'. ${ }^{102}$ 'Turkish nationalists are Muslims, but they are not Islamists', ${ }^{103}$ wrote Sançar, and added that political Islamists were making a big mistake by assuming that they could glorify Islam by undermining Turkishness. ${ }^{104}$

At the same time as the Atsiz circle was repositioning as the secular alternative to the Islamic-leaning Turkish nationalists, significant developments were taking place in the Turkish political scene. After a two-year-long exile, Alparslan Türkeş was finally allowed to return in 1963 and he immediately set about transforming what was until then a social movement into a political party. He mobilized some loyal members of the Fourteen and nationalist youth all over the country to join the Republican Peasant-Nation Party (Cumhuriyetçi Köylü Millet Partisi, RPNP), a minor party on the centre-right that was suffering from a chronic leadership struggle. Gaining control of party organs from within, Türkeş became the new party leader in $1965 .{ }^{105}$ His plan was to overhaul the RPNP and remake it as the only party of the Turkish radical right. Timing could not have been better, because the closure of the DP after the 1960 coup released the milliyetçi-mukaddesatçı voters and the non-Kemalist nationalist intellectuals from their half-hearted alliance with the centre-right and, moreover, a not insignificant percentage of centre-right voters moved to the radical right under the impact of the sham trials of the former DP leadership and subsequent execution by hanging of former Prime Minister Adnan Menderes and two other cabinet members. New centre-right parties, founded after the return to multi-party democracy in 1961, were extremely careful not to provoke the military and, therefore, could not meet radical right demands for justice for the still imprisoned DP elite and vengeance for the 'martyred prime minister'.

The great irony of Alparslan Türkeş' political career was that his target audience held him - at least partially - responsible for the coup and the terrible end of Menderes, ${ }^{106}$ who, following his execution, turned into a right-wing martyr and the patron saint of democracy in Turkey. Those few months in 1960 during which Türkeş was the strongman of the junta continued to haunt him throughout his career and stood in his way well into the 1970s, preventing him from consolidating his control over radical right votes. Right before the 1969 general elections, for example, the Nurcus, 
who had thrown their support behind Süleyman Demirel's Justice Party, used their extensive network in Anatolia to distribute a propaganda pamphlet that accused Türkeş of being an unbeliever, among many other things. One of the co-authors of the pamphlet was Bekir Berk, who had converted from being a nationalist leader to the Nurculuk Movement during the 1950s, showing the permeability of the border that separated nationalists from the Islamists. ${ }^{107}$

Knowing too well that this could nip his political career in the bud, Türkeş' followers tried to recast his image even before his return to Turkey. İsmet Tümtürk published a copy of Türkeş' 1961 letter from exile to his former colleagues in the junta, warning them not to carry out death sentences against Menderes and his ministers. ${ }^{108}$ The biggest obstacle that stood between Türkeş and success in the ballot box, however, was the question of Islam, and more had to be done in this regard than Tümtürk's occasional journal articles that portrayed Türkeş as the 'pious colonel'.

Indeed, at the beginning, Türkeş' RPNP looked just like another secular party in the Turkish political system. The 254-article-long party programme mentioned religion only in Articles 16 and 17, whose content was so weak and spiritless that they could probably be found in any other right-wing party programme at the time. ${ }^{109}$ Other early party documents either repeated the same line, or bypassed the topic altogether. ${ }^{110}$ Likewise, the new guiding principles of nationalist politics, the socalled 'Nine Lights' doctrine, published under the name of Türkeş in 1965, did not contain any reference to religion. Türkeş defined the principle of moralism (ahlâkç̧llk), for example, in a strictly nationalist framework, suggesting vaguely that 'Turkish morality ought to be in harmony with Turkish tradition, Turkish spirit, and the beliefs of the Turkish nation', without explaining what those beliefs were. ${ }^{111}$ Any explicit reference to Islam was conspicuously absent at this point in the discourse of Türkeş and his party. ${ }^{112}$

However, electoral defeats in, first, the general elections in 1965, and then the senate elections in 1966, showed beyond doubt the impracticality of the policy of reaching out to the milliyetçi-mukaddesatçı voter base as long as the RPNP did not adopt a more Islamic jargon. By 1967, Türkeş was seriously considering an Islamic turn and his right-hand man in the party, Dündar Taşere, ${ }^{113}$ laid the foundations of a new nationalist discourse, which incorporated Islam as the most important marker of Turkish identity. Türkeş articulated this new policy line in his address to the Eighth Congress of the RPNP in 1967, where he began to use the term 'Muslim-Turkish nation', and invited everyone to 'the Islamic morality and virtue ... to the path of truth, to the path of GOD'. He entered the congress centre as thousands chanted 'Allahüekber' (God is great) and, following the secular ritual of observing a moment of silence, Türkeş and others raised their hands up and said Islamic prayers in Arabic. RPNP members, Türkes demanded in his address, had to read 'the Book [the Koran]' of the people and endeavour to 'connect the corridors of technical universities, science faculties and laboratories with the corridors of theological schools'. ${ }^{114}$ Türkeş' speech was an unmistakable sign of the transformation of the RPNP from a secular to an Islamic-leaning nationalist party. When Osman Yüksel Serdengeçti joined the RPNP group in the Turkish parliament in April 1968 with great fanfare and invited all milliyetçi-mukaddesatçı voters to follow him, the sea change in party ideology was symbolically confirmed. ${ }^{115}$ 
On the other hand, those developments should not be taken to mean that Türkeş and Taşer were able to push them through without opposition. The secular faction within the party - to which Türkeş himself once belonged - was by no means ineffective, nor was it only composed of a bunch of old-timers, living in a fantasy world. The fact that their numbers dwindled within the party rank and file did not mean that their voice was heard less. Numan Esin, a member of the Fourteen, resigned from the party in July 1967, citing 'retreat from the Atatürkist path' as the immediate reason for his resignation, and he was followed by two other members of the Fourteen, Şefik Soyuyüce and Münir Köseoğlu, as well as the party secretary Mustafa Kaplan in $1968 .^{116}$ The departure of high-ranking party members and old colleagues put enormous pressure on Türkeş, who was trying to hold the party together as the 1969 general elections were approaching. The final and potentially most serious challenge to his authority, however, came from the Atsiz circle right before and during the Ninth RPNP Congress in February 1969.

Only months away from the general elections in October, Türkeş and Taşer wanted to use the party congress as a public relations stunt to showcase their new doctrine. The Ninth Congress was planned to reaffirm change by two enormously significant acts: adopting a new party name and an emblem to replace those that had been inherited from the former party leadership. ${ }^{117}$ These two questions had been on the party's agenda since 1967, but they were postponed until 1969 due to lack of consensus on, particularly, what the new emblem should be. There was no serious objection to the new party name, the Nationalist Action Party (Milliyetçi Hareket Partisi, NAP), but the Islamic-leaning majority within the party supported a new emblem composed of three crescents, which symbolized the Islamic-Ottoman past, whereas the Atsiz faction refused to accept any emblem but the long-standing symbol of panTurkism, the grey wolf. The conflict between the two groups, the so-called crescentists (hilalciler) and wolfists (kurtçular) threatened to split the party into two and proved once more the divisive potential of religious questions. ${ }^{118}$ Türkeş did not openly declare support for one of the proposed emblems, but he clearly sided with the crescentists and tried to make sure that the conflict over the emblem would cause the party the least possible damage. In all likelihood, the decision to hold the congress in the backwater town of Adana was the outcome of this calculation. More likely destinations such as Ankara or İstanbul posed serious challenges, because members of the Atsiz faction were concentrated in those two cities and could have exerted disproportionate influence over congress proceedings by filling the congress centre with supporters.

Knowing that the wolfist Atsiz youth would in any case be a minority at the congress, Türkeş hoped to save them the embarrassment of defeat and his party an immense trauma, which could only lead to secession. Negotiations over the new emblem, therefore, continued until the last moment, but a face-saving formula could not be found. The two different visions of non-Kemalist nationalism had now become enemies and they collided head-on on 9 February 1969 in what turned out to be a zero-sum battle over the soul of the party. No one doubted the winner. After a long day of fiery speeches and occasional resort to physical violence, which involved forcibly removing the Atsiz youth from the building, the crescentists carried the day. ${ }^{119}$ This was a historical event that marked the most important turning point in the history of Turkish nationalism since 1944. The clash between the secular and 


\section{I. Aytürk}

Islamic-leaning branches had finally reached a boiling point and however much Türkeş wanted to avoid direct confrontation, in the end he was left with no other choice but to dethrone Atsiz, the intellectual father of non-Kemalist nationalism. In the following months and years, the Atsiz circle continued its activities mainly in İstanbul, but lost its political influence over party policy-making. With the passing of Atsiz and Sançar in 1975, the secular vein in non-Kemalist nationalism died out and while Atsiz still commanded respect for his other views and uncompromising character, his secular approach to Islam became a taboo subject in nationalist politics and virtually impossible to revive.

Was this the inevitable outcome? To paraphrase Darendelioğlu and Çetinsaya, shall we conclude that interpretations of Turkish nationalism, which relegated Islam to a secondary role in the making of Turkishness, were nothing but aberrations from the normal course of events? Can we, for instance, consider the Atsiz phenomenon an inexplicable and unimportant gap in the otherwise regular pattern of Islamic-leaning nationalism $?^{120}$ Indeed, the majority of the non-Kemalist nationalists converted to an Islamic discourse in the aftermath of the 1969 Adana Congress. The Islamic turn in Turkish nationalism had become so entrenched and seemed so irreversible that it led many academic observers to project this trend backwards in time to the late nineteenth century and the first half of the twentieth, ignoring profound ill-feelings between nationalists and Islamists during this period. Actually, nationalist politicians and academics in Turkey did not even stop there and pushed the temporal boundaries of a 'Turkish-Islamic Synthesis' (Türk-Islam Sentezi) or 'Turkish-Islamic

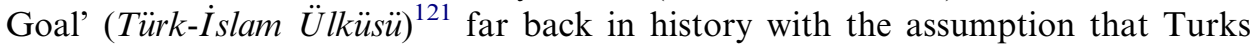
had developed a symbiotic relationship with Islam since their conversion in the tenth and eleventh centuries. Yet the evidence presented in this article points to the conclusion that, before 1969, there was no consensus among Turkish nationalists over the question of Islam. On the contrary, Islam was rather the most controversial topic that produced regular infighting and alienated nationalist factions from each other.

The Islamic discourse, which started to appear in nationalist publications during the 1950s for the first time and became dominant after 1969, was hardly a symptom of a natural affinity, nor does it justify an essentialist approach. To put it differently, the two discourses did not click immediately and naturally; the Islamic turn in Turkish nationalism was clearly a product of demographic change, anti-Kemalist sentiments, and electoral behaviour in Cold War Turkey. Moreover, the rise of political Islam cannot be regarded as a singularly Turkish phenomenon either. The Islamist challenge to secular regimes in the 1960s and 1970s shook the foundations of many Arab and non-Arab countries in the Middle East and Turkey was not an exception. ${ }^{122}$ Unlike pan-Arab nationalism, which saw Islam as the greatest achievement of the Arab people and therefore embraced it, Turkish nationalism developed a very strong secular streak from the beginning. After all, Turkish nationalism was born as a secular response to the failure of pan-Ottomanism and pan-Islamism in arresting the decline of the empire. Its politically dominant Kemalist branch had always been explicitly secular, while even within the non-Kemalist nationalism secularists made a strong comeback with the Atsiz circle, that is until they, too, were politically extinguished for good in 1969. 


\section{Notes}

This article was written during my stay at the Department of Near Eastern Languages and Civilizations, University of Chicago as a Fulbright Fellow. I would like to thank my host Holly Shissler for creating the best research environment. My thanks also go to Gavin Brockett, who sent me extensive comments on a slightly different, earlier version. If I did persist in some of my views, it's not for lack of good advice.

1. I.E. Darendelioğlu, Türkiye’de Milliyetçilik Hareketleri (n.p.: Toker, 1968), p.8.

2. G. Çetinsaya, 'Rethinking Nationalism and Islam: Some Preliminary Notes on the Roots of "Turkish-Islamic Synthesis" in Modern Turkish Political Thought', The Muslim World, Vol.89 (1999), p.351. Hakan Yavuz makes the same point in his, 'Nationalism and Islam: Yusuf Akçura and $\ddot{U} c ̧$ Tarz-ı Siyaset', Journal of Islamic Studies, Vol.4 (1993), pp.175-207.

3. Çetinsaya, 'Rethinking Nationalism', p.376.

4. The literature on Gökalp is vast. For an overview of his ideas, see U. Heyd, Foundations of Turkish Nationalism: The Life and Teachings of Ziya Gökalp (London: Luzac, 1950); N. Berkes, Turkish Nationalism and Western Civilization: Selected Essays of Ziya Gökalp (New York: Columbia University Press, 1959); T. Parla, The Social and Political Thought of Ziya Gökalp, 1876-1924 (Leiden: Brill, 1985); A. Davison, 'Secularization and Modernization in Turkey: The Ideas of Ziya Gökalp', Economy and Society, Vol.24 (1995), pp.189-224; A. Davison, Secularism and Revivalism in Turkey (New Haven, CT: Yale University Press, 1998).

5. E. Güngör, 'Ziya Gökalp ve “Türkçülük’te Din” Meselesi', in E. Güngör et al. (eds.), Atsız Armă̆anı (İstanbul: Ötüken, 1976), pp.267-80.

6. B. Ayvazoğlu, Tanrıdă̆ı’ndan Hıra Dă̆ı’na: Milliyetçilik ve Muhafazakarlı Üzerine Yazılar (İstanbul: Kap1, 2010), p.162.

7. B. Anderson, Imagined Communities: Reflections on the Origin and Spread of Nationalism (London: Verso, 1991), pp.5-6.

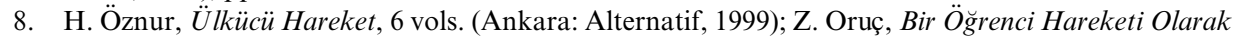
Milli Türk Talebe Birliği (İstanbul: Pınar, 2005); E.B. Arıkan, Milliyetçi Hareket Partisi: Türk Să̆ının Türk Sorunu (İstanbul: Agora, 2008).

9. D. Kushner, The Rise of Turkish Nationalism, 1876-1908 (London: Frank Cass, 1977); M. Arai, Turkish Nationalism in the Young Turk Era (Leiden: Brill, 1992).

10. F. Georgeon, Aux origines du nationalism turc: Yusuf Akçura (Paris: ADPF; 1980); B.E. Behar, Iktidar ve Tarih: Türkiye'de Resmi Tarih Tezi'nin Oluşumu, 1929-1938 (İstanbul: Afa, 1992); F. Üstel, Imparatorluktan Ulus-Devlete Türk Milliyetçiliği: Türk Ocaklarl, 1912-1931 (İstanbul: İletişim, 1997); E. Copeaux, Espaces et temps de la nation turque: Analyse d'une historiographie nationaliste, 1931-1993 (Paris: CNRS, 1997); J.P. Laut, Die Türkische als Ursprache? Sprachwissenschaftliche Theorien in der Zeit des erwachenden türkischen Nationalismus (Wiesbaden: Harrassowitz, 2000); A. Yıldız, Ne Mutlu Türküm Diyebilene: Türk Ulusal Kimliğinin Etno-Seküler Sintrlart, 1919-1938 (İstanbul: İletişim, 2001); S. Cagaptay, Islam, Secularism and Nationalism in Modern Turkey: Who Is a Turk? (London: Routledge, 2006).

11. G.G. Özdoğan, "Turan”dan “Bozkurt”a: Tek Parti Döneminde Türkçülük (1931-1946) (İstanbul: İetişim, 2001); N. Önen, İki Turan: Macaristan ve Türkiye’de Turancllık (İstanbul: İletişim, 2005).

12. T. Bora and K. Can, Devlet, Ocak, Dergâh: 12 Eylül'den 1990'lara Ülkücü Hareket (İstanbul: İletişim, 1991); T. Bora and K. Can, Devlet ve Kuzgun: 1990'lardan 2000'lere MHP (İstanbul: İletişim, 2004).

13. For some notable exceptions, see J.M. Landau, Radical Politics in Modern Turkey (Leiden: Brill, 1974), pp.193-242; J.M. Landau., Pan-Turkism (Bloomington: Indiana University Press, 1995); Bora and Can, Devlet, Ocak, Dergâh; Bora and Can, Devlet ve Kuzgun; Y. Taşkın, Milliyetçi Muhafazakar Entelijensiya: Anti-Komünizmden Küreselleşme Karşıtlı̆̆ına (İstanbul: İletişim, 2007); G.D. Brockett, How Happy To Call Oneself a Turk: Provincial Newspapers and the Negotiation of a Muslim National Identity (Austin: University of Texas Press, 2011).

14. Pan-Turanism flourished among the early twentieth century Hungarian nationalists in the Habsburg Empire and Turkic intellectuals in the Russian and Ottoman Empires. For the Hungarian branch, see, J. Kessler, 'Turanism and Pan-Turanism in Hungary, 1890-1945' (PhD thesis, University of California, Berkeley, 1967). The Turkish branch supported the unification of all Turkic peoples under the umbrella of a single political state. Turkish Pan-Turanism evolved into Racist-Turanism 


\section{I. Aytürk}

after the 1930s under the leadership of Nihal Atsiz. See Naval Intelligence Division, A Manual on the Turanians and Pan-Turanianism (London: His Majesty's Stationery Office, 1918); Özdoğan, "Turan"dan "Bozkurt”a; Önen, Iki Turan.

15. The Anatolianist Movement was born in the journals Dergâh and Anadolu in the 1920s, but reached a wider audience when it was taken over by Remzi Oğuz Arık and Nurettin Topçu. The Anatolianists argued that the Turkic Oghuz tribes, which migrated to Anatolia from the eleventh to the fourteenth centuries, developed a distinct national identity, separating them from their ethnic kinsmen in Inner Eurasia. The emphasis on Anatolia and their view of Racist-Turanism as adventurism drove a wedge between them and the Atsiz circle.

16. The Intellectuals' Hearth was an elitist, right-wing think-tank club, established in the 1960s to fight against the leftist predominance in arts, literature and political thought. The movement's political influence grew by leaps and bounds in the 1970s and 1980s, as exemplified by the adoption of the Turkish-Islamic Synthesis, the signature contribution of the Hearth to right-wing cultural politics, by nearly all Turkish governments ever since. See S. Basmacı, 'Aydınlar Ocă̆ı ve Türk-İslam Sentezi' (MA thesis, Hacettepe University, 2009); F. Yurttaş Özcan, 'Bir Aydın Hareketi Olarak Aydınlar Ocağı ve Türk Siyasetine Etkileri' (PhD thesis, University of Sakarya, 2011).

17. The most understudied of all nationalist movements in Cold War Turkey, National-Strugglism (Yeniden Milli Mücadele) was an anti-imperialist, anti-communist, anti-Semitic and Islamist movement with an elitist bend. See F.B. Araba, 'Yeniden Milli Mücadele Hareketi ve Din' (MA thesis, University of Sakarya, 2009).

18. N. Berkes, The Development of Secularism in Turkey (Montreal: McGill University Press, 1964); S..A. Mardin, 'Ideology and Religion in the Turkish Revolution', International Journal of Middle East Studies, Vol.2 (1971), pp.197-211; B. Toprak, Islam and Political Development in Turkey (Leiden: Brill, 1981); I. Kara, Cumhuriyet Türkiye’sinde Bir Mesele Olarak Islam (İstanbul: Dergâh, 2008); I. Gözaydın, Diyanet: Türkiye Cumhuriyeti’nde Dinin Tanzimi (İstanbul: İletişim, 2009); A. Bein, Ottoman Ulema Turkish Republic: Agents of Change and Guardians of Tradition (Stanford, CA: Stanford University Press, 2011).

19. Çetinsaya, 'Rethinking Nationalism and Islam', p.362. However, this is not to say that Islam did not figure at all in Kemalist policies. There is now a growing body of literature which has shown that the secular Kemalists pursued discriminatory policies against non-Muslim minority groups in the early republican period. Discriminatory policies have continued up to this day even under non-Kemalist governments. It needs to be emphasized though that early republican policies had little, if anything, to do with Islamic camaraderie and should rather be explained within the framework of the catastrophic ethnic conflicts that brought the Ottoman Empire to an end.

20. C.O. Tütengil, Dr. Rıza Nur Üzerine (Ankara: Üçler, 1965); T. Özakman, Dr. Rıza Nur Dosyası (Ankara: Bilgi, 1995).

21. S. Öner, Nihâl Atsız (İstanbul: Toker, 1977); A. Deliorman, Tanıdı̆̆ım Atsız (İstanbul: Boğaziçi, 1978); A. Suver, Nihal Atsız (İstanbul: Su, 1978); O.F. Sertkaya, Nihâl Atsız (Ankara: T.C. Kültür ve Turizm Bakanlı̆̆ı1, 1987); H. Tek, Nihal Atsız (Ankara: Alternatif, 2002); C. Özdemir, Atsız Bey: Hüseyin Nihal Atsı'ın Hayatı, Fikirleri ve Romanlart Üzerine Bir Ínceleme (İstanbul: Ötüken, 2007); H. Öznur, Ülkücü Hareket, Vol.6, Portreler (n.p.: n.p., 1999), pp.3-99; U. Uzer, 'Racism in Turkey: The Case of Hüseyin Nihal Atsiz [sic]', Journal of Muslim Minority Affairs, Vol.22 (2002), pp.119-29; J.M. Landau, 'Ultra-Nationalist Literature in the Turkish Republic: A Note on the Novels of Hüseyin Nihâl Atsız', Middle Eastern Studies, Vol.39 (2003), pp.204-10; İ. Aytürk, 'The Racist Critics of Atatürk and Kemalism from the 1930s to the 1960s', Journal of Contemporary History, Vol.46 (2011), pp.308-35.

22. N. Sefercioğlu, Çiftçioğlu Nejdet Sançar: Hayatı ve Eserleri (Ankara: Türk Ocakları, 2006).

23. T. Bora, 'Nationalist Discourses in Turkey', The South Atlantic Quarterly, Vol.102 (2003), pp.433-51.

24. Ü. Cizre-Sakallığlu, 'Kemalism, Hyper-Nationalism and Islam in Turkey', History of European Ideas, Vol.18 (1994), pp.255-70.

25. N. Mert, 'The Political History of Centre Right Parties: Discourses on Islam, the Nation and the People', in S. Yerasimos, G. Seufert and K. Vorhoff (eds.), Civil Society in the Grip of Nationalism: Studies on Political Culture in Contemporary Turkey (İstanbul: Orient-Institut, 2000), pp.49-97.

26. Cetinsaya, 'Rethinking Nationalism and Islam', p.368; J. Salt, 'Nationalism and the Rise of Muslim Sentiment in Turkey', Middle Eastern Studies, Vol.31 (1995), p.15. 
27. By choosing this policy line, RPP set a precedent for the following five decades of coaxing extreme nationalist groups into fighting proxy wars on behalf of the Turkish state against leftists and Kurds at home and Armenians abroad. Each time, however, these groups were brutally suppressed (1944, 1953, 1980 and 1990s) when they outlived their usefulness.

28. C. Koçak, İkinci Parti: Türkiye'de İki Partili Siyasi Sistemin Kuruluş Yılları, 1945-1950, Vol.1 (İstanbul: İletişim, 2010).

29. F. Ertuğrul, Hasan Âli Yücel-Kenan Öner Davası (Ankara: Güldikeni, 2000); H.Â. Yücel, Dâvam (Ankara: Ulus, 1947); K. Öner, Öner ve Yücel Davast (İstanbul: n.p., 1947); K. Öner, Öner ve Yücel Davast 2 (İstanbul: n.p., 1947).

30. Müftüoğlu, 'Atsız'la Konuştum', Kızılelma, No.3 (14 Nov. 1947), pp.8-10 and 16.

31. Denizcioğlu, 'Milliyetçi Bir Partiye Şiddetle İhtiyaç Var!', Kızılelma, No.6 (5 Dec. 1947), pp.3 and 14; Denizcioğlu, 'Milliyetçi Partinin Temel Taşı', Kızılelma, No.7 (12 Dec. 1947), pp.3 and 12; Denizcioğlu, 'Demokratlara Selâm!', Kızılelma, No.9 (26 Dec. 1947), pp.3 and 14; Denizcioğlu, 'Milliyetçi Partiye Doğru', Kızılelma, No.12 (16 Jan. 1948), pp.3 and 14-15. On the expectation that Hamdullah Suphi Tanrı̈ver might lead a nationalist bloc, see İT. Noyan, 'Hamdullah Suphi Tanrı̈ver'in Halk Partisi'nden Çekilmesi', Kızılelma, No.11 (9 Jan. 1948), pp.3 and 15.

32. Millet Partisi, Program ve Tüzük (Ankara: Teknik, 1948); Millet Partisi, Millet Partisi Müessislerin [sic] ve Fahri Bașkan Mareșal Fevzi Çakmak Tarafından Millete Yayınlanan Beyanname (Ankara: n. p., 1948); M. Atabay, 'Çok Partili Dönemde Bir Muhalefet Partisi: Millet Partisi (20 Temmuz-194827 Ocak 1954)' (MA thesis, University of Ankara, 1991); N. Onak, 'Millet Partisi: Türk Siyasal Hayatında 1960'a Kadar Doldurduğu Yer' (PhD thesis, University of İstanbul, 1993).

33. S. Külçe, Mareşal Fevzi Çakmak: Askeri, Siyasi, Hususi Hayatı (İzmir: Yeni Asır, 1946); S. Külçe, Mareşal Fevzi Çakmak, 2 vols. (İstanbul: Cumhuriyet, 1953); H. Gök, Mareşal Fevzi Çakmak’ın Askeri ve Siyasi Faaliyetleri, 1876-1950 (Ankara: Genelkurmay, 1997); R. Akbaş, Mareşal Fevzi Çakmak (İstanbul: Ötüken, 2008).

34. H.H. Hyman, A. Payaslioglu and F.W. Frey, 'The Values of Turkish College Youth', The Public Opinion Quarterly, Vol.22 (1958), pp.275-91; H.H. Hyman, A. Payaslioglu and F.W. Frey, The Turkish Political Elite: Study in Comparative Policy (Cambridge, MA: MIT Press, 1965); H.H. Hyman, A. Payaslioglu and F.W. Frey, 'Socialization to National Identification among Turkish Peasants', The Journal of Politics, Vol.30 (1968), pp.934-65; L.L. Roos, Jr. and N.P. Roos, Managers of Modernization: Organization and Elites in Turkey (1950-1965) (Cambridge, MA: Harvard University Press, 1971); L.L. Roos, Jr., N.P. Roos and G.R. Field, 'Students and Politics in Turkey', Daedalus, Vol.97 (1968), pp.184-203.

35. Recently available autobiographies contain numerous anecdotes that confirm the feeling of alienation; see, N. Kösoğlu, Hatıralar, Yahut Bir Vatan Kurtarma Hikayesi (İstanbul: Ötüken, 2008); Y. Okuyan, O Ylllar (İstanbul: Doğan, 2010); A. Karabacak, Üç Hilalin Hikayesi (İstanbul: Bilge Oğuz, 2011); E. Kılınç, Damla Damla Yaşadıklarım (İstanbul: Ötüken, 2012); and for a slightly different trajectory, N. Yalçıntaş, Türkiye’yi Yükselten Yillar: Hatıralar (İstanbul: İşaret, 2012).

36. Support for the NP was 3.11 per cent in the 1950 general elections, which was only a fraction of its expected votes.

37. Aytürk, 'The Racist Critics of Atatürk and Kemalism', pp.318-20; B. Ayvazoğlu, 'Ah, O Eski Ülkücüler', Türkiye Günlüğ̈̈, No.50 (March-April 1998), p.181.

38. Darendelioğlu, Türkiye'de Milliyetçilik, p.225.

39. Ibid., p.226.

40. Ibid., pp.228-30; 'Türk Milliyetçileri Birleşti', Komünizme Karşı Mücadele, No.18 (15 April 1951), pp.1 and 4; 'Türk Milliyetçiler Derneği', Orkun, No.28 (13 April 1951), pp.8-9.

41. 'Türk Milliyetçileri Birleşti', p.4.

42. Ibid.

43. U. Spuler, 'Nurculuk: Die Bewegung des Bediüzzaman Said Nursi in der modernen Türkei', Bonner Orientalistische Studien, Vol.27 (1973), pp.100-183; Ș. Mardin, Religion and Social Change in Modern Turkey: The Case of Bediüzzaman Said Nursi (Albany, NY: SUNY Press, 1989).

44. http://www.risalehaber.com/news_detail.php?id=108164 (accessed 2 May 2012).

45. A. Çinar, 'National History as a Contested Site: The Conquest of Istanbul and Islamist Negotiations of the Nation', Comparative Studies in Society and History, Vol.43 (2001), pp.364-91.

46. Türk Milliyetçiler Derneği İstanbul Şubesi, Ayasofya (İstanbul: Şaka, 18 April 1952); I.H. Danişmend, 'Ayasofya Camii', Komünizme Karşı Mücadele, No.33 (1 April 1952), p.2; B. Berk, 
'Başbakan Adnan Menderes'e Açık Mektup', Komünizme Karşı Mücadele, No.34 (15 April 1952), pp.1 and 4; 'İsmail Hami Danişmend Bey’le Yaptığımız Konuşma', No.34 (15 April 1952), p.23; O.Y. Serdengeçti, 'Ayasofya', Serdengeçti, No.17 (Aug. 1952), p.3.

47. Deliorman, Tanıdı̆̆ım Atsız, pp.90-93; Ayvazoğlu, Tanrıdă̆ı'ndan Hıra Dă̆ı’na, p.145.

48. A European-trained archaeologist by profession, Arık was the mentor of the Anatolianism Movement and the leader of the Türkiye Köylü Partisi (Peasant Party of Turkey). Two of his works, Ideal ve İdeoloji (İstanbul: Kutulmuş, 1947) and Coğrafyadan Vatana (Ankara: Yeni, 1956) contain dominant themes of the Anatolianist branch of Turkish nationalism.

49. Deliorman, Tanıdı̆̆ım Atsız, p.51.

50. Kazganoğlu, 'Taassup', Orkun, No.8 (24 Nov. 1950), p.12; İ. Tümtürk, 'İnkılâp-İrtica', Orkun, No.17 (26 Jan. 1951), p.3; H. Karamağralı, 'Türk Kültür Derneği’nin Cevabı', Orkun, No.18 (2 Feb. 1951), p.16; 'Mukkadesatına Bağlı Gençliğin Sesi', Orkun, No.22 (2 March 1951), p.14; Ç.N. Sançar, 'Komünizm ve İrtica Meselesi', Orkun, No.23 (9 March 1951), pp. 3-4; N. Tarhan, 'İtica Var!', Orkun, No.26 (30 March 1951), p.7; Çivicioğlu, 'Hürriyet, Hakikat ve Adalet Yolunda Adımlar', Orkun, No.27 (6 April 1951), p.11; Çivicioğlu, 'Hürriyet, Hakikat ve Adalet Yolunda Adımlar', Orkun, No.28 (13 April 1951), pp.10-12; H.F. Gözler, 'Din ve Kaytaklık', Orkun, No.30 (27 April 1951), p.9; 'Irtica İlerliyor!', Orkun, No.43 (27 July 1951), p.8; 'Dün ve Bugün', Orkun, No.46 (17 Aug. 1951), p.8.

51. N. Atsız, 'Türk Ahlâkı', Orkun, No.43 (27 July 1951), pp.3-4.

52. At least some of the perpetrators were members of the TNS. See İ. Tümtürk, 'Başbakan'a Hitap', Orkun, No.30 (27 April 1951), pp.3-4; I. Tümtürk, 'Yine Kütahya Meselesi', Orkun, No.33, 18 May 1951, pp.3-4. The TNS published two pamphlets to refute those allegations; see, Türk Milliyetçiler Derneği Umumi Merkezi, Türk Milletine Beyanname (n.p.: Güven, 24 April 1952); Türk Milliyetçiler Derneği İstanbul Şubesi, Son Hadiseler ve Biz (İstanbul: M. Sıralar, 9 Jan. 1953).

53. Darendelioğlu, Türkiye'de Milliyetçilik, pp.259-60.

54. Ibid., pp.260-63.

55. Deliorman, Tanıdı̆̆ım Atsız, pp.113-18.

56. İ.H. Danişmend, Türk Irkı Niçin Müslüman Olmuştur? (İstanbul: Okat, 1959).

57. Ibid., pp.46-7, 51-3, 57.

58. Ibid., p.3.

59. S. Kaplan, "'Religious Nationalism”: A Textbook Case from Turkey', Comparative Studies of South Asia, Africa and the Middle East, Vol.25 (2005), p.671.

60. A. Türkocağı, Türklük ve Íslamiyet (Adana: Gürpınar, 1966), pp.17, 19-35; MHP İstanbul İ Gençlik Teşkilatı, 50. Yıla Doğru (İstanbul: Ergenekon, 1973), p.32; A. Türkeş, Ahlâkçılık (İstanbul: Dokuz Işık, 1977), pp.36-7, 49; S.H. Bolay, 'Türk İnsanının ve Cemiyetinin Teşekkülünde Dinin Rolü', Milli Eğitim ve Kültür, No.1 (1 Dec. 1978), pp.31-43; A. Ocağ1, Milliyetçiler III. Büyük İlmî Kurultayı Kararları (İstanbul: Aydınlar Ocağı 1978), p.37; A. Ocağı, Millî Ĕ̆itim ve Din Hayatı: Milliyetçiler III. Büyük İlmî Kurultayı, Tebliğler, Açıklamalar, Müzakereler (İstanbul: Boğaziçi, 1981), pp.314 and 319; E. Güngör, Tarihte Türkler (İstanbul: Ötüken, 1988), pp.61-9; E.R. Fı̆̆lalı, 'Din ve Türkler', in S. Başer (ed.), Türk Münevverinin Müşterek Fikir ve Îman Zemîni (İstanbul: Kubbealt1, 1988), pp.13-18.

61. Danişmend, Türk Irkl, pp.205-8. His other works include Garb Membalarına [sic] Göre Eski Türk Seciyye ve Ahlâkı (İstanbul: Yeni, 1961); Garp Menba’larına [sic] Göre Eski Türk Demokrasisi (İstanbul: Sucuoğlu, 1964); Türklük Meseleleri (İstanbul: İstanbul, 1966).

62. A. Balcıoğlu, Osman Yüksel Serdengeçti (İstanbul: IQ, 1991); R. Y1lmaz, Toros Yüzlü Adam: Osman Yüksel Serdengeçti (İstanbul: Nesil, 1998); H. Öznur, O. Yüksel Serdengeçti (Ankara: Alternatif, 2002).

63. A. Özcan, Osman Yüksel ve Serdengeçti Dergisi (İstanbul: Türk Edebiyatı Vakfı, 2010).

64. S.S. Ögüun, Türkiye'de Cemaatçi Milliyetçilik ve Nurettin Topçu (İstanbul: Dergâh, 1992); Ç. BalimHarding, 'Last of the Anatolian Nationalists: Nurettin Topçu', in C. Hillenbrand (ed.), The Sultan's Turret: Studies in Honour of Cliffor Edmund Bosworth, Vol.2 (Leiden: Brill, 1999), pp.1-18; H. Karaman, Nurettin Topçu'da Ahlâk Felsefesi (İstanbul: Dergâh, 2000); L. Şehsuvaroğlu, Nurettin Topçu (Ankara: Alternatif, 2002); B. Dural, Başkaldırı ve Uyum: Nurettin Topçu ve Türk Muhafazakârlı̆̆l (Ankara: Birharf, 2005); F. Mollaer, Anadolu Sosyalizmine Bir Katkl: Nurettin Topçu Üzerine Yazılar (İstanbul: Dergâh, 2007); F. Mollaer, Türkiye'de Liberal Muhafazakarlık ve Nurettin Topçu (İstanbul: Dergâh, 2008); İ. Kara (ed.), Nurettin Topçu (Ankara: T.C. Kültür Bakanlı̆̆ı, 2009); L. Şehsuvaroğlu, Türk Sosyalizmi ve Nurettin Topçu (Ankara: Elips, 2011). 
65. N. Topçu, Garbın İlim Zihniyeti ve Ahlâk Görüşü (İstanbul: Milliyetçiler Derneği, 1955); N. Topçu, Taşralı (İstanbul: Kutulmuş, 1959); N. Topçu, Türkiye’nin Maarif Davası (İstanbul: Milliyetçiler Derneği, 1960); N. Topçu, Yarınki Türkiye (İstanbul: Yağmur, 1961); N. Topçu, Kültür ve Medeniyet (İstanbul: Hareket, 1970).

66. Aytürk, 'The Racist Critics', pp.326-33.

67. N. Atsız, 'Nurculuk Denen Sayıklama', Ötüken, No.3 (16 March 1964), pp.2 and 4; N.: Atsız, 'İslâm Birliği Kuruntusu', Ötüken, No.4 (17 April 1964), p.9; N. Atsı, 'Sağc1 Kimdir?', Ötüken, No.50 (Feb. 1968), p.3; N. Sançar, 'Genç Türkçülere Mektuplar: I', Ötüken, No.59 (Nov. 1968), pp.8-9.

68. E. Özbudun, The Role of the Military in Recent Turkish Politics (Cambridge, MA: Center for International Affairs, Harvard University, 1966); K. Karpat, 'The Military and Politics in Turkey: 1960-1964', The American Historical Review, Vol.65 (1970), pp.1654-83.

69. A. Türkeş, 1944 Milliyetçilik Olayı, 14th edition (İstanbul: Kamer, 1992); H. Turgut, Türkeş'in Anıları: Şahinlerin Dansı (İstanbul: ABC Basın Ajans, 1995).

70. E. Örtülü, $\ddot{U} c ̧$ İhtilâlin Hikâyesi (Ankara: Ayyıldız, 1966); E. Maraşlı, Darbe İçinde Darbe: 13 Kasım 1960 Ondörtler Olayı (İstanbul: Bilge Ŏ̆uz, 2010).

71. The only source of information on Türkeş' New Delhi years is the memoir of Taner Baytok, who was then a young Turkish diplomat there; see his Dış Politikada Bir Nefes (Ankara: Remzi, 2005).

72. N. Atsız, Ordinaryüs'ün Fahiş Yanlışlarl: Ali Fuat Başgil'e Cevap (İstanbul: Küçükaydın, 1961); N. Atsız, 'Milliyetçilik Taslayan İhtiyar Kozmopolit', Ötüken, No. 8 (15 Aug. 1964), pp.1-2; H. Ilgar, Sözde ve Gerçek Milliyetçilik: Atsız-Başgil Mücadelesinin İç Yüzü (İzmir: Ülkü, 1964).

73. 'Alparslan Türkeş Hakkında Bir Görüş', Millî Yol, No.6, 2 March 1962, pp.8-9.

74. 'Nurculuk Meselesi', Millî Yol, No.42 (16 Nov. 1962), pp.10-11; 'Nurculuk Meselesi', Millî Yol, No.43 (23 Nov. 1962), pp.8-11; 'Nurculuk Meselesi: 2', Milli Yol, No.44 (30 Nov. 1962), pp. 8-10; İ. Tümtürk, 'Nurculuk Meselesi: 3', Millî Yol, No.47 (21 Dec. 1962), pp.13-14. The anonymous author of the first three articles was Tümtürk, too.

75. 'Milli Yol Neşriyatına Ara Veriyor', Millî Yol, No.48 (28 Dec. 1962), p.3.

76. The Society of Turkists was going to be renamed the Union of Nationalists in Turkey (Türkiye Milliyetçiler Birliği) in 1964, and the Society of the Union of Nationalists in Turkey (Türkiye Milliyetçiler Birliği Derne ği) in 1965.

77. Deliorman, Tanıdı̆̆ım Atsız, pp.332 and 362-4.

78. K.F. Coşkuner, 'Atsız Bege [sic] Açık Mektup', Fedai, No.10 (May 1964), pp.10-13; 'Orkundan Haberler', Orkun, No.21 (Oct. 1963), p.31.

79. A thorough treatment of Atsız's approach to Islam can be found in F.S. Sanlı, 'Türkçülük Akımında Din Olgusu Üzerine Aykırı Bir Yaklaşım: Hüseyin Nihal Atsız ve Fikirleri' (MA thesis, University of Ankara, 2010).

80. N. Sançar, 'Gerçekseverlere Bildiri II', Ötüken, No.7, 16 July 1964, pp.4-9; N. Sançar, 'Yobaz ve Sahte Yobaz', Ötüken, No.41 (May 1967), pp.5-6; N. Atsı, 'Sağc1 Kimdir?', Ötüken, No.50 (Feb. 1968), pp.3-4; G.Y. Yücel, 'Türklük Bir Bütündür', Ötüken, No.56 (Aug. 1968), pp.10-11; H. Ilgar, 'Öze Dönüş', Ötüken, No.65 (May 1969), p.9.

81. Sançar, 'Gerçekseverlere Bildiri II', p.5.

82. Yücel, 'Türklük Bir Bütündür', pp.10-11.

83. Atsı, 'Nurculuk Denen Sayıklama', p.1.

84. For the latest book making this argument, see E. Manela, The Wilsonian Moment: Self-Determination and the International Origins of Anticolonial Nationalism (New York: Oxford University Press, 2007).

85. N. Atsız, 'Uydurma Milliyetçilik', Ötüken, No.2 (14 Feb. 1964), pp.6-7; Atsız, 'İslâm Birliği Kuruntusu', p.7.

86. N. Atsız, 'Milliyetçi Gençlik', Ötüken, No.15 (22 March 1965), p.1.

87. N. Sançar, 'Türk Milletinin Tarifi', Ötüken, No.4 (17 April 1964), p.2.

88. N. Sançar, 'Gerçekseverlere Bildiri III', Ötüken, No.9 (12 Sept. 1964), pp.3-4.

89. H. Ilgar, 'Faydasız ve Yanlış Bir Terim', Ötüken, No.28 (30 April 1966), p.13. Also see Gökçeoğlu, 'Türklük Bir Bütündür', pp.10-11; 'Orkundan [sic] Haberler', p.31.

90. Atsız, 'Uydurma Milliyetçilik', pp. 6-7; Atsız, 'Nurculuk Denen Sayıklama', p.1; Atsı, 'İslâm Birliği Kuruntusu', pp.7-8; A. Okçuoğlu, 'Nurculuk ve Komünizm', Ötüken No.35 (November 1966), p.9; M. Z. Sofuoğlu, 'Türk Milliyetçiliğinde İkilik Yaratanlar', Ötüken, No.41 (May 1967), pp.6-7; K. Dikici, 'Türkçülük ve Din', Ötüken, No.51 (March 1968), p.13; Gökçeoğlu, 'Türklük Bir Bütündür', pp.10-11; H. Ilgar, 'Yazık, Çok Yazık', Ötüken, No.15 (22 March 1965), p.11; H. 
Ilgar, ‘Öze Dönüş’, Ötüken, No.65 (May 1969), p.9; N. Sançar, 'Din Perdesi Arkasında Türkçülük Düşmanlığı', Ötüken, No. 66 (June 1969), p.5.

91. Atsı, 'Sağc1 Kimdir?', pp.3-4; Sançar, 'Gerçekseverlere Bildiri II', pp.5-6; H. Ilgar, 'İstikametler Belli Olmalıdır', Orkun, No.24 (25 Jan. 1964), pp.21-2.

92. Atsı, 'Sağc1 Kimdir?', p.3.

93. Ibid., pp.3-4.

94. Atsız, 'İslâm Birliği Kuruntusu', pp.7-9.

95. Ibid. For a more thorough articulation of anti-Arab sentiment, see 'Arap Aklı!' and 'Türk'ü İnkâr', Orkun, No.19 (Aug. 1963), p.17; 'Mantık', Orkun, No.22 (30 Nov. 1963); N. Sançar, 'Türk Adları', Ötüken, No.11 (14 Nov. 1964), pp.3-4; R. Cantaş, 'Korkak! Açık Konuş', Ötüken, No.11 (14 Nov. 1964), p.7; 'Türkiye Milliyetçiler Birliği Üsküdar Ocağının [sic] Çalışmaları', Ötüken, No.12 (15 Dec. 1964), p.11; Kocakurt, 'Arap-İsrail Savaşı', Ötüken, No.42 (June 1967), p.6; E. Yakuboğlu, 'İsrail'i Arap Liderler Yarattı', Ötüken, No.43 (July 1967), pp.6-7; O. Özgedik, Komünizmle Mücadelede Türkçülük, Müslümanlık ve Politika (İzmir: Hoşgönül, n.d.); E.A. Kolukısa, Dinde Türkçülüğe Dönüşs (Ankara: Ayyıldız, 1970); F. Çil (ed.), Kavgamız Türkçülük Kavgası (Turan Dergisi Yayınıdır) (İstanbul: Turan Dergisi, 1977), p.69.

96. Atsız, 'Uydurma Milliyetçilik', pp.6-7; 'Kısa Bir Kürek', Ötüken, No.28 (30 April 1966), p.12; A. Okçuoğlu, 'Türkçülük Düşmanı Bir ümmetçi [sic]: Necip Fazıl', Ötüken, No.37 (Jan. 1967), pp.4-5; 'Cüce ve Bücür', 'Haçlilar', 'Irk Meselesi', Ötüken, No.37 (Jan. 1967), p.7; 'Tapmak Meselesi', 'Şeyh ve Kerametleri', 'Üstada Layık Gazete', Ötüken, No.38 (Feb. 1967), p.16; Sofuoğlu, 'Türk Milliyetçiliğinde İkilik Yaratanlar', pp.6-7; 'Azıtan Yobaz', 'Kavmiyet Teranesi', 'Din Sömürücülüğü', 'Iftira', 'Yobaza Bir Ders', 'Tanrı Türk’ü Korusun', Ötüken, No.41 (May 1967), pp.15-16; 'Samimi Dindar ve Yobaz', 'Bir Soru', 'Yobaza Kötü Haber', Ötüken, No.42 (June 1967), p.16; N. Atsı, 'Dindar ve Mutaassıp Hacı Bayanın Türklüğe Hakaretleri', Ötüken No.64 (April 1969), pp.3-5.

97. Atsı, 'Nurculuk Denen Sayılama', p.1.

98. Ibid. Also see İ.H. Gökhun, 'Müslümanlık ve Türklük Anlayışı', Ötüken, No.8 (15 Aug. 1964), pp.5-6; 'Said-i Kürdici’ye', Ötüken, No.12 (15 Dec. 1964), p.7; 'Nurculuk', Ötüken, No.15 (22 March 1965), p.9; 'Debreli Hasan', Ötüken, No.33 (Sept. 1966), p.11; A. Tuğcu, 'İslamiyet ve Nurculuk', Ötüken, No.33 (Sept. 1966), p.19; R. Cantaş, 'Bir Tarihçiye Açık Mektup', Ötüken, No.34 (Oct. 1966), pp.8-9; Okçuoğlu, 'Nurculuk ve Komünizm', p.9; N. Atsız, 'Konuşmalar', Ötüken, No.40 (April 1967), pp.2-10; K. Dikici, 'Bu Nasıl Milliyetçilik?', Ötüken, No.54 (June 1968), p.11.

99. Atsız, 'Konuşmalar', p.10.

100. N. Sançar, 'Gerçekseverlere Bildiri', Ötüken, No.6 (15 June 1964), p.2.

101. N. Sançar, 'Bildiri', Ötüken, No.24 (16 Dec. 1965), p.12.

102. Türkiye Milliyetçiler Birliği, Türkiye Milliyetçiler Birliği’nin Görüşü: İlk Bildiri (Ankara: Mors, 1964), pp.7-8. This document was co-signed by four leading members of the circle, Nejdet Sançar, Hikmet Tanyu, Haluk Karamağralı and Zeki Sofuoğlu. Although Atsız was not one of the co-signatories, it could only have been published after his approval.

103. Sançar, 'Gerçekseverlere Bildiri II', p.6.

104. N. Sançar, 'Türklük ve İslâmlık Meselesi', Ötüken, No.54 (June 1968), pp.8-9.

105. H. Öznur, Ülkücü Hareket, Vol.1, CKMP'den MHP'ye (n.p.: Alternatif, 1999), pp.98-103.

106. Ayvazoğlu, Tanrıdă̆ı'ndan Hıra Dă̆ı'na, p.155.

107. B. Berk and M. Polat, Tarihi Vesikaların Işı̆̆̆ Altında İslami Hareket ve Türkeş (İstanbul: İttihad Gazetesi, 1969). For the nationalist response, see Milliyetçi ve Mukaddesatçı Türk Gençliği, İslâmî Hareket ve Türkeş: If ftiralara Cevaplar (İstanbul: n.p., n.d.). The damage to the electoral campaign, however, was admittedly crippling; see Okuyan, $O$ Yillar, pp.28-9.

108. 'Türkeş'in Gürsel'e Mektubu', Millî Yol, No.1 (26 Jan. 1962), p.7; 'Alparslan Türkeş'in İdam Cezalarının İnfazından Sonraki Yeni Bir Mektubu', Millı Yol, No.10 (30 March 1962), p.5.

109. Müreffeh ve Kuvvetli Türkiye İçin CKMP Programı (Ankara: Arı, n.d. [1965]), pp.7-8; Müreffeh ve Kuvvetli Türkiye İçin C.K.M.P. Programı (Ankara: Ayyıldız, 1965), pp.7-8.

110. Cumhuriyetçi Köylü Millet Partisi, Temel İlkelerimiz, Ana Dâvalarımız, Ícraat Plânımız (Ankara: Ayyıldız, 1965); Cumhuriyetçi Köylü Millet Partisi, Türk Gençliği İçin: CKMP Hizmet Plânı (Ankara: Ayyıldız, 1965). 
111. A. Türkeş, Dokuz Işık (İstanbul: Dokuz Işık, 1965), p.4. Future editions of this book (in 1973 and 1976 for example) were going to expand on this topic and discuss it exclusively from the vantage point of Islam. The most succinct version of Türkeş's views on Islam can be found in his Ahlâkçılık.

112. For two exceptions, see H. Tanyu, Kale: Imanın, Ahlakkın ve Hakikatın Kalesi (Afyon: Bozkurt, 1965); Y.̇. Hakk1, Üç Büyük Tehlike: Siyonizm, Komünizm, Farmasonluk (İstanbul: Güven, 1969).

113. Taşer's role during the metamorphosis of the RPNP is not duly appreciated. Some of his ideas are kept for posterity by posthumous collections of anecdotes and articles; see D. Taşer, Mesele Second Edition (Ankara: Töre-Devlet, 1973); Z.N. [Aksun], Dündar Taşer'in Büyük Türkiye'si, 2nd edition (İstanbul: Kutluğ, 1976).

114. Öznur, Ülkücü Hareket, Vol.1, pp. 151-2.

115. Öznur, Ülkücü Hareket, Vol.1, pp.154-5.

116. Ibid., p.160. N. Esin, Devrim ve Demokrasi: Bir 27 Mayısçının Anıları (İstanbul: Doğan, 2005), pp.249-53; Öznur, Ülkücü Hareket, Vol.1, pp.143-53. Öznur gives a later date for Esin's resignation and quotes extensively from his letter of resignation addressed to Türkeş.

117. Ibid., pp.166-7.

118. Ibid., p.191.

119. Ibid., pp.168-96.

120. For an excellent discussion on racism in contemporary Turkey, see, M. Ergin, 'Is the Turk a White Man? Towards a Theoretical Framework for Race in the Making of Turkishness', Middle Eastern Studies, Vol.44 (2008), pp.827-50.

121. The first term was coined by the Intellectuals' Hearth (Aydınlar Ocă̆ $\iota$ ) in the late 1960s and gained currency in following decades as the official cultural policy of right-wing Turkish governments. The second, however, first appeared in the writings of Seyyid Ahmed Arvasi in the 1970s and became a linchpin of NAP doctrine.

122. S. Zubaida, 'Islam and Nationalism: Continuities and Contradictions', Nations and Nationalism, Vol.10 (2004), pp.407-20; Salt, 'Nationalism and the Rise of Muslim Sentiment', p.13. 